NBER WORKING PAPER SERIES

\title{
COMPLEXITY AND TARGETING IN FEDERAL STUDENT AID: A QUANTITATIVE ANALYSIS
}

\author{
Susan Dynarski \\ Judith E. Scott-Clayton \\ Working Paper 13801 \\ http://www.nber.org/papers/w13801 \\ NATIONAL BUREAU OF ECONOMIC RESEARCH \\ 1050 Massachusetts Avenue \\ Cambridge, MA 02138 \\ February 2008
}

This paper is forthcoming in Tax Policy and the Economy, Volume 22 (2008), edited by James Poterba. We benefited from comments from seminar participants at the Brookings Institution, College Board, Consortium on Financing Higher Education, Harvard University, National Bureau of Economic Research, National Tax Association and Stanford University. We extend particular thanks to Sandy Baum, Sandy Jencks and Tom Kane. Scott-Clayton is grateful for financial support from the National Science Foundation. The views expressed herein are those of the author(s) and do not necessarily reflect the views of the National Bureau of Economic Research.

NBER working papers are circulated for discussion and comment purposes. They have not been peerreviewed or been subject to the review by the NBER Board of Directors that accompanies official NBER publications.

(C) 2008 by Susan Dynarski and Judith E. Scott-Clayton. All rights reserved. Short sections of text, not to exceed two paragraphs, may be quoted without explicit permission provided that full credit, including (๑) notice, is given to the source. 
Complexity and Targeting in Federal Student Aid: A Quantitative Analysis

Susan Dynarski and Judith E. Scott-Clayton

NBER Working Paper No. 13801

February 2008

JEL No. H0,H21,I2,I22,I28

\begin{abstract}
$\underline{\text { ABSTRACT }}$
A growing body of empirical evidence shows that some financial aid programs increase college enrollment. Puzzlingly, there is little compelling evidence that Pell Grants and Stafford Loans, the primary federal student aid programs, are effective in achieving this goal. In this paper, we provide an in-depth review of this evidence, which taken as a whole suggests that complexity and uncertainty in the federal aid system undermine its efficacy. We document complexity in the aid system, comparing it in particular to complexity in the tax system. We build on our previous work by showing that complexity in the aid process does little to improve the targeting of both student loans and grants, for both dependent and independent students. We conclude that the current targeting of aid can be reproduced with a much simpler aid process. While we show that the targeting benefits of complexity are small, we further document that the costs are large. We offer new estimates of the compliance costs faced by applicants and the administrative costs borne by the government and colleges. These costs total at least $\$ 4$ billion per year. The perspective of behavioral economics suggests that the true cost is even higher, since complexity and uncertainty may discourage the target population from applying for student aid.
\end{abstract}

\author{
Susan Dynarski \\ Harvard University \\ Kennedy School of Government \\ 79 JFK Street \\ Cambridge, MA 02138 \\ and NBER \\ susan_dynarski@ksg.harvard.edu \\ Judith E. Scott-Clayton \\ Harvard University \\ Kennedy School of Government \\ 79 JFK Street \\ Cambridge, MA 02138 \\ jscottc@nber.org
}




\section{Introduction}

Each year, ten million households seeking federal aid for college complete a detailed questionnaire about their finances, the Free Application for Federal Student Aid (FAFSA). At five pages and 127 questions, the FAFSA is slightly longer than IRS Form 1040 and substantially longer than Forms 1040EZ and 1040A. Since the majority of households use the shorter IRS forms, for the typical household their aid application is longer and more complicated than their federal tax return.

Complexity in the federal tax code has received considerable attention from economists and been the focus of reform efforts for decades. Researchers have made substantial progress in conceptualizing and calculating the compliance burden created by the tax system, which encompasses the time and effort required to understand the tax code, to maintain relevant financial records, and to fill out forms. ${ }^{1}$

In stark contrast, complexity in financial aid has received little attention from researchers. As college attendance has expanded, the financial aid process has affected an increasing proportion of US households. The burden this process imposes on families is of increasing policy relevance, as even moderate compliance costs when summed over millions households create substantial costs to the economy. Further, complexity in the aid process may undermine the efficacy of aid in achieving its purpose, which is to make college an option for those who could not otherwise afford to attend. If complexity burdens those on the margin of college entry, it could well blunt the impact of aid on their schooling decisions. Contributing to this concern is the fact that the aid process is not only complex but also highly uncertain, with definitive information about freshmen-year aid not revealed until after college applications are filed, in the spring of the senior year in high school. Those high school students most sensitive to cost may not even apply to college if they do not know it is affordable, so the back-loading of information in this setting may be particularly costly.

In this paper, we use the perspectives of both classical and behavioral economics to examine the costs of complexity in student financial aid. We have explored this topic in previous work (Dynarski and Scott-Clayton, 2006 and 2007). The current paper extends this work along several dimensions. First, we

\footnotetext{
${ }^{1}$ Kaplow $(1990,1996)$ lays out a framework for considering the costs to individuals, firms and government of complexity in the tax code. Blumenthal and Slemrod (1992) calculate the time cost of compliance for individual taxpayers. Berube, et al. (2002) focus on compliance costs for the Earned Income Tax Credit. Goolsbee (2004) explored whether tax software reduces the costs of complexity for individual taxpayers. Holtzblatt and McCubbin (2004) focus on the impact of complexity on low-income taxpayers.
} 
provide a comprehensive review of the literature on the causal impact of student aid on outcomes, discussing why standard estimates of this relationship are likely to be biased. We highlight what the evidence suggests about the optimal design of financial aid programs. Second, we broaden our quantitative analysis to include the important topic of student loans, which now dominate the federal student aid budget. Third, the present analysis includes both dependent and independent students, while Dynarski and Scott-Clayton (2006) considered only dependent students. Independent students (students older than 24, or who are married or have children) now comprise 47 percent of undergraduate students. They receive 58 percent of Pell Grant funds and 56 percent of Stafford subsidized loan dollarss, so they are of undeniable policy relevance. Fourth, we provide a more detailed discussion of the time costs of completing the FAFSA, focusing in particular on how the FAFSA questions differ from those on the 1040.

We estimate that the financial cost of complexity is at least four billion dollars a year. Ten million FAFSAs are filed each year. We estimate that, on average, the FAFSA takes about ten hours to complete. Assuming the current, average hourly wage of $\$ 17.50$, we estimate a time cost of $\$ 1.75$ billion per year. Additionally, colleges spend over \$2 billion annually on salaries for staff who administer federal financial aid or other aid based on the federal aid formula. Colleges are also statutorily required to audit at least 30 percent of these aid applications; at least three million such audits take place annually. By comparison, the Internal Revenue Service (IRS) audit rate on personal income tax returns is 1.5 percent, or two million audits per year. The time costs of FAFSA audits add to the costs of the aid application process.

The non-financial costs of complexity are less certain. Economic theory and empirical evidence predict that complexity and uncertainty in aid could undermine its ability to affect schooling decisions. A long-standing theoretical and experimental literature suggests that even seemingly minor differences in program design can have profound impacts upon behavior (Kahneman and Tversky, 2000). A burgeoning empirical literature has demonstrated that these predictions hold in real-life situations (Madrian and Shea, 2001). Empirical evidence on the behavioral impact of aid suggests that complexity in the aid system undermines its efficacy. While simple, easily communicated aid programs have been shown to have a robust impact on college entry and completion, we have little to no compelling evidence that the 
traditional forms of student aid (which require a FAFSA) increase schooling for their target populations. Complexity may be the culprit. Simply put, potential college students cannot respond to a price subsidy if they do not know it exists.

While the bounds on the costs of complexity are wide, we show that its benefits are conclusively miniscule. With student-level data from the 2003-04 National Postsecondary Student Aid Survey (NPSAS:04), we find that much of the complexity in the aid system does little to improve the targeting of aid. Nearly all of the variation in aid is generated by a handful of the more than 70 data items used in the aid formula. Adjusted gross income (or, for tax non-filers, earnings from work), marital status, family size, and the number of family members in college explain over three-quarters of the variation in federal grant aid. For three-quarters of applicants, this simplified aid formula produces grants within $\$ 100$ of the grants produced by the current formula. For about 85 percent of students, simulated grants are within $\$ 500$ of current grants. A new contribution of the present paper is to provide analogous estimates for subsidized student loans. Eligibility for these loans is determined through the same process used for Pell Grants. As we show, the overwhelming majority of the variation in subsidized loan eligibility is explained by a handful of data items.

The items that we find drive eligibility for loans and grants —adjusted gross income and family size - are already collected via income tax forms. Aid eligibility could be determined using existing tax information, and the aid application could be eliminated. This approach is similar in spirit to a "no-return" tax system, in which tax authorities use data they already have collected to determine tax liability (Government Accounting Office, 1996; Gale and Holtzblatt, 1997). A key lesson of our research is that we can substantially reduce complexity and uncertainty in the aid system if we are willing to tolerate minor imperfections in measuring ability to pay. Reducing complexity appears to have little potential downside and improves the likelihood that aid will serve its intended goal: opening the doors of college to those who have the ability but not the means to further their education. 


\section{Student Aid in the US}

Two programs provide the bulk of federal aid to college students: the Pell Grant and the Stafford Loan. Pell grants average $\$ 2,500$ per recipient, with a maximum value of $\$ 4,050$. Pell Grants flow almost exclusively to families with incomes below $\$ 40,000$ (Stedman, 2003). During the 2004-05 academic year, \$13.6 billion in Pell Grants was delivered to over five million students (College Board, 2005). During the same year, \$55 billion in loans was delivered to undergraduates through the Stafford Loan program. Half of the Stafford loans distributed are need-based "subsidized" loans, for which the government pays the interest while the student is in college. The other half is "unsubsidized" Stafford loans, for which interest accrues during college. While the unsubsidized loans are provided regardless of need, students must go through the need-determination process to access them. Dependent undergraduates can borrow \$2,625 for the first year of college, $\$ 3,500$ for the second year and $\$ 5,500$ in each of the next three years. ${ }^{2}$ Stafford loans do not require a credit check. Parents can borrow unsubsidized loans up to the cost of college (net of aid) through the federal PLUS program, which does require a credit check and for which interest accrues during college (U.S. Dept. of Education, 2005b).

\section{Evidence on the Impact of Student Aid}

A simple model of human capital unambiguously predicts that subsidizing college costs raises the privately-optimal level of schooling. While the theoretical predictions are clear, it is an empirical question how much a given dollar of subsidy affects behavior. Answering this empirical question is a challenge, since eligibility for subsidies is certainly not random. Rather, aid is offered to students on the basis of characteristics that have their own effect on the probability of college attendance. For example, Pell Grants flow to low-income youth. If these students are relatively unlikely to attend college, perhaps because of low levels of parental education or low-quality secondary schooling, then estimates of the effect of aid based on this source of variation in aid will be downwardly biased. Conversely, since many colleges use merit scholarships to attract high-achieving students, the bias on estimates of the effect of aid

\footnotetext{
${ }^{2}$ Beginning in the 2007-08 academic year, loan limits will increase to \$3,500 for the first year and \$4,500 for the second year.
} 
will, in some cases, be positive. Since many studies in this literature pool all sources of aid into a single variable, it is frequently impossible to sign the bias on a given estimate.

We can attempt to eliminate this bias by controlling for a vector of regressors. Common covariates include measures of financial resources, such as parental income, and measures of individual ability, such as standardized test scores. Whatever the particular empirical strategy or functional form, these studies share the common assumption that controlling for observables can absorb individual differences correlated with schooling decisions and schooling costs. Under plausible conditions, this approach will fail. First, we may not properly model the schooling decision, by omitting relevant variables or including them in the wrong functional form. Second, even if we correctly model the schooling equation, data on relevant characteristics may simply be unavailable. For example, parental wealth affects schooling decisions, both directly and through eligibility for aid, but complete information on parental wealth is rarely available in survey data, especially among adults who have completed their education.

In sum, the omitted variables problem may be unsolvable using standard multiple regression methods. One solution is a randomized, controlled trial, in which aid amounts are randomly assigned to a pool of potential college students. Such an experiment has never been fielded. Alternatively, the analyst can use observational data to study the outcome of a natural, or quasi, experiment, in which a discrete shift in aid policy differentially affects observationally identical individuals. We next describe the evidence from such studies.

Dynarski (2003) takes advantage of variation in grant eligibility induced by the elimination of the Social Security student benefit program in the early Eighties. From 1965 to 1982, the Social Security Administration paid for millions of students to go to college. Under this program, the 18- to 22-year-old children of deceased, disabled or retired Social Security beneficiaries received monthly payments while enrolled full-time in college. The average annual payment in 1980 to the child of a deceased parent was 
$\$ 6,700$. At the program’s peak, 12 percent of full-time college students aged 18 to 21 were receiving Social Security student benefits. ${ }^{3}$

In 1981, Congress voted to eliminate the program. Enrollment sank rapidly and by the 1984-85 academic year, program spending had dropped by \$3 billion. Except for the introduction of the Pell Grant program in the early 1970s, and the various GI Bills, this is the largest and sharpest change in grant aid for college that has ever occurred in the United States. Using difference-in-differences methodology, and proxying for benefit eligibility with the death of a parent during an individual's childhood, Dynarski (2003) finds that the elimination of the Social Security student benefit program reduced college attendance probabilities of the affected group by more than a third. These estimates suggest that an offer of $\$ 1,000$ in grant aid increases the probability of attending college by about 3.6 percentage points.

A more recent set of policy innovations has provided variation in aid that has proved valuable to researchers. Since the early Nineties, over a dozen states have established broad-based merit aid programs. In 1993, Georgia introduced the Georgia HOPE (Helping Outstanding Pupils Educationally) Scholarship, funded by a state lottery. The program allows free attendance at Georgia's public colleges for state residents maintain at least a B average in high school and college. Those attending private colleges are eligible for an annual grant that roughly equals average tuition at the public universities. Dynarski (2000) estimates the impact of Georgia's program by comparing changes in college attendance rates in Georgia to changes in other southeastern states during the same time period. The effect of HOPE is identified by differences between Georgia and the rest of the southeastern United States in the time trend of college attendance rates. She finds that the program substantially increased college entry in Georgia, by 4 to 6 percentage points per $\$ 1,000$ in aid. Research on similar state programs has also shown them to be effective in increasing college attendance (Abraham and Clark, 2006; Kane, 2003; Dynarski, 2004a and forthcoming). The programs also appear to increase the share of young people completing a college degree (Dynarski, forthcoming). Effects are strongest among women, especially Blacks and Hispanics.

\footnotetext{
${ }^{3}$ Statistics in this paragraph are drawn from Table 54 in Social Security Administration (1982), Table A in College Board (1998) and Table 174 in US Department of Education (1998).
} 
This body of research has established that young people are sensitive to college costs in making their schooling decisions. In fact, from a rational perspective, they appear to be "too" sensitive, given how small the direct costs of college are. At the typical public college, required tuition and fees average $\$ 6,000$; at a community college they are closer to $\$ 2,000$ (College Board, 2006). These costs are quite small when weighed against the lifetime return to a college degree. On average, college graduates make fifty percent more than high school graduates (College Board, 2004). These returns accrue for decades, whereas tuition costs accumulate for only a few years. The strong response of young people to the aid programs just described provides indirect evidence that present costs loom very large for this population. All of the programs discussed above are outside of the traditional, federal student aid system. What about the traditional programs? There is little to no persuasive evidence that the federal aid programs are similarly effective - or at all effective - in increasing the college enrollment of young people. This lack of evidence does not reflect lack of effort: the Pell Grant program has received considerable attention from researchers. Hansen (1983) examined enrollment rates before and after implementation of the Pell Grant program. Hansen found that while enrollment rates of all income groups increased during the 1970s, enrollment among low-income students did not increase disproportionately. Kane (1995) utilizes more years of data and limits the sample to women, whose enrollment patterns were less disrupted by the Vietnam War than those of men, but is also unable to find an effect. Bettinger (2004) uses regression-discontinuity analysis to examine whether the Pell Grant reduces the dropout rate among college students; his results suggest this is the case but he stresses that his estimates are too sensitive to specification and functional form to draw strong conclusions. Just one study using quasi-experimental methods compellingly estimates an effect of the Pell on schooling decisions: Seftor and Turner (2002) find a small but robust effect on the college attendance of older, independent students.

When examined as a whole, this body of evidence is puzzling. How can some aid programs produce such large, robust impacts while the others have little detectable effect? The populations are similar: the Social Security student benefit program served families similar to that served by Pell: lowincome, nonwhite, disproportionately headed by single parents. The merit aid programs appear to have 
been particularly effective for Blacks and Hispanics. So the answer is not that the population served by Pell is insensitive to price.

A striking difference between the effective programs and the traditional programs is in the paperwork requirements they impose on applicants. The HOPE application consists of a half-page of basic biographical information. High schools proactively send transcript data to the state in order to identify scholarship winners. Application requirements were even simpler in the Social Security student benefit program. The Social Security Administration proactively sent a letter to each beneficiary shortly before the $18^{\text {th }}$ birthday, asking about college plans. If the beneficiary was planning on college, benefit checks continued to arrive. Renewal required only confirmation of enrollment from the college registrar. By contrast, the traditional aid programs impose complicated paperwork and procedural requirements on applicants. We describe this process in detail in the next sections.

A second difference between the effective aid programs and the traditional aid programs is in the extent to which students understand the programs and can accurately estimate their eligibility in the years preceding college. In the case of the Social Security program, families knew exactly the benefits they would receive, since a student who qualified simply received the child benefits that had previously gone to her family. Similarly, people are quite knowledgeable about the Georgia HOPE program. More than seventy percent of Georgia high-school freshmen are able to name the program without prompting. Fiftynine percent, when asked to list some requirements of HOPE, volunteer that a high school GPA of 3.0 is necessary (Henry, et al, 1998). This level of knowledge about a government program would be remarkable among adults; it is even more striking among young teenagers. By contrast, a US Government Accounting Office (GAO) analysis found that nearly ninety percent of high school sophomores in 1980 did not know about the Pell Grant program (US GAO, 1990). 


\section{The Financial Aid Form}

Establishing eligibility for federal aid is called "need determination." The data elements that determine "need" are collected in the FAFSA, which is required for all federal grants and loans. ${ }^{4}$ From information on the FAFSA, the U.S. Department of Education computes the expected family contribution (EFC), an estimate of how much the family can pay out of pocket for college. "Need" is defined as the difference between the cost of attendance (e.g., tuition, fees, books, living expenses) and this family contribution. The basics of need-determination have changed little since they were laid out over fifty years ago. In 1953, John Monro, dean of admissions at Harvard College, described to his colleagues at a College Board conference the formula he used to assign financial aid to Harvard admits. The assembled aid administrators were eager to establish a common formula for assigning aid, so that they could quash the competitive bidding for the best students that that had recently developed among elite colleges. Within a year, a common aid application was in use (Duffy and Goldberg, 1998; Wilkinson, 2005). The schools that initiated this need-determination process typically enrolled students from families with relatively high incomes and asset holdings, and so sought detailed measures of wealth and income so that they could measure need among families with complicated financial situations. ${ }^{5}$ As we next show, today's FAFSA reflects its history, providing extremely fine measures of ability to pay at levels of income that far exceed the effective cutoffs for federal aid.

The FAFSA collects detailed information about the student’s and parents' income, assets and various other benefits and expenditures. In Table 1 we compare the FAFSA to the IRS 1040, 1040A and 1040EZ income tax forms (see http://www.ifap.ed.gov/fafsa/0607FinalFAFSA.html for a copy of the 2006-07 FAFSA). The FAFSA, at five pages and 127 questions, is longer than Form1040EZ (one page, 37 questions) and Form 1040A (two pages, 83 questions). It is comparable to Form 1040 (two pages, 118 questions). ${ }^{6}$ For the families targeted by need-based aid, complexity in the aid application rivals the complexity they experience in the income tax system. Most families eligible for the Pell file the shorter 1040A or 1040EZ; 86 percent of filing households with income below $\$ 50,000$ (and two-thirds of all

\footnotetext{
${ }^{4}$ Most state aid and school scholarships also require the FAFSA. Some colleges require an additional aid application, such as the College Board's PROFILE or a school-specific form.

${ }^{5}$ Until 1973, the federal aid application asked about make and model of the family car (Wilkinson, 2005).

${ }^{6}$ Unless otherwise noted, FAFSA question counts are for dependent students, who must answer questions about their parents' finances as well as their own.
} 
households) use these simplified IRS forms. The contrast between Form 1040EZ and the FAFSA is especially striking. With a third of the FAFSA's questions and a fifth of its pages, the IRS captures the information needed to determine tax liability for the very population targeted by need-based aid.

Why is the FAFSA so long? As Table 1 shows, the FAFSA captures finer measures of financial resources than the tax forms. Thirty-three FAFSA questions probe for sources of income not shown on the $\mathrm{W}-2$, compared to two on the 1040EZ, 12 on the 1040A and 19 on the 1040 . Further, while none of the tax forms ask about assets, the FAFSA has six questions on this topic. And because the aid formula applies different "tax rates" to the student and parents, the FAFSA inquires twice about each financial resource, once of the parents and once of the student. ${ }^{7}$

As we will show later in the paper, there are few questions on the FAFSA that low-income families can simply ignore. Most of the questions apply to individuals of any income, including those about child support and "other untaxed income not reported elsewhere.” Several, such as those about welfare and EITC benefits, are only relevant for low income families. We now move to describing the broader application process of which the FAFSA is just a part.

\section{The Financial Aid Process}

We have just described the process of filling out a FAFSA, which is similar in length to a 1040 . There is a key difference between the aid and tax forms, however. When a taxpayer has completed her 1040, she knows how much tax she owes. More than twenty of the questions on the 1040 are calculations or look-ups in tax tables that allow filers to arrive at this bottom-line of tax liability. Completing the FAFSA yields absolutely no information about aid eligibility. In fact, definitive information about aid eligibility does not arrive until months after the FAFSA is submitted, in the spring before college enrollment.

Figure 1 illustrates the student aid process. Prospective freshmen typically file a FAFSA in spring of their senior year of high school. Many schools require that the FAFSA be filed by March 1, but

\footnotetext{
${ }^{7}$ The marginal tax rate on parental income ranges from 22 to 47 percent, while for student earnings the tax rate is zero below an earnings protection allowance and 50 percent above that allowance. The highest tax rate on parental assets is about six percent for each year of college, while the student's assets can be taxed at 35 percent (this rate will fall to 20 percent as of the 2007-2008 academic year). See Dynarski (2004b) for a discussion of how the aid tax on assets varies by ownership and asset type.
} 
students are not allowed by the Department of Education to file a FAFSA until January 1 . Once the FAFSA is submitted, the U.S. Department of Education computes the EFC. The EFC, but not any estimate of aid eligibility, is mailed to the applicant as well as the colleges to which she has applied (U.S. Department of Education, 2005d).

The federal government does not notify students of their federal aid eligibility; rather, this is left to the colleges to which students are admitted. Colleges use the EFC to personalize a package of grants and loans for each student, which they then mail out in award letters, typically in March and April. Only upon receiving these award letters do students learn about their federal aid for the upcoming year.

\section{A Quantitative Analysis of the Benefits of Complexity}

Complexity in the aid system arises from efforts to precisely measure ability to pay for college. The design of the current federal aid system reveals a social preference to focus grant funds on "needy" students. The rationale for the FAFSA is that its detailed questions allow aid administrators to identify these needy students. The marginal contribution of each question to this targeting goal can be quantified, and in this section we undertake this exercise. Our goal is to measure the benefits of complexity: the degree to which it improves the targeting of aid. These benefits can then be weighed against the costs of complexity, which we explore in the next section.

To preview the results: we find that that of the 127 questions on the FAFSA only a handful have any substantial effect on the distribution of student aid. Most of the FAFSA could be eliminated without doing violence to the revealed distributional priorities of the federal aid programs.

\section{Empirical Methodology}

We use individual-level data from the restricted-use, nationally representative 2003-04 National Postsecondary Student Aid Survey (NPSAS:04) to examine the relationship between federal aid received and information in the FAFSA. The NPSAS:04 includes FAFSA data for 56,440 undergraduate federal aid applicants. We limited our sample to 26,156 full-time undergraduates (dependent or independent) who attended the same institution for the full year. From this sample we drop 1,733 individuals who were 
missing an EFC, as well as 170 individuals missing other critical data elements such as income or family size. This results in a final sample of 24,253 individuals.

We focus on Pell Grants and subsidized loans, the most expensive components of federal needbased aid. To replicate each student's Pell and loan eligibility, as well as to test the consequences of formula simplification, we coded the 2003-04 EFC, Pell, and Stafford loan formulas and rules for dependent and independent students as outlined in the 960-page 2003-2004 Federal Student Aid Handbook (U.S. Department of Education, 2003a).

The federal EFC formula for dependent students adds together parents’ adjusted gross income (or W-2 earnings for non-tax-filers) and other income. It then subtracts a number of allowances, of which the largest is taxes paid, and adds in 12 percent of parents' assets over an asset protection allowance that depends on parents' ages and marital status (for example, the allowance is $\$ 42,200$ for a married couple in which the older parent is 45). Retirement savings and the value of a primary home are not counted as assets. The resulting figure is called parents' adjusted available income (AAI). A progressive marginal assessment rate from 22 to 47 percent is applied to this number, and the result is then divided by the number of children in college to obtain the parents’ expected contribution.

The dependent student's expected contribution is computed by summing the student's adjusted gross income and other income, subtracting a few allowances, and applying a 50 percent assessment rate. Thirty-five percent of any student assets are added to this figure to yield the student's expected contribution. Students have no asset protection allowance. The final EFC is obtained by adding the student's expected contribution to the parents' expected contribution.

The expected contribution for independent students with children is calculated much like that of the parents of dependent children. The expected contribution of independent students without children is calculated much like that of dependent students, but with higher income and asset allowances. The total contribution is divided by the number of family members in college to calculate the EFC.

For both dependent and independent students, the Pell Grant is awarded by subtracting the EFC from the maximum Pell Grant $(\$ 4,050)$. Following federal rules, grants between $\$ 0$ and $\$ 199$ are rounded down to \$0, and grants between \$200 and \$399 are rounded up to \$400. Pell Grants of over \$2,700 are 
adjusted downward for students at very-low-tuition institutions (tuition and fees of less than \$675 in 2003-04) using what is called the tuition sensitivity adjustment. Pell Grants are also reduced if the calculated amount exceeds the cost of attendance at the student's institution (which is provided in NPSAS, as reported by the schools). Among full-time students in our sample, the tuition sensitivity adjustment applied to only 35 students and the cost of attendance adjustment applied to none. Subsidized Stafford loan eligibility is estimated by subtracting the estimated EFC, estimated Pell grant, and any other grants from the cost of attendance. The result is capped at the maximum loan amount for the student's class level and dependency status.

We first use the NPSAS data to replicate aid under the current formula, and compare these calculated amounts with their actual values as documented in the NPSAS. Our predicted aid values are extremely close to their actual values. Regressing the actual against the predicted values yields an $\mathrm{R}^{2}$ of 1.00 for the EFC and 0.997 for the Pell Grant. ${ }^{8}$ To measure the influence of the various FAFSA components on aid, we sequentially exclude data items from the aid formula, recalculate aid, and compare the simulated aid amounts to the baseline values described above. ${ }^{9}$ Mechanically, this is achieved by setting the value of the excluded items to zero. ${ }^{10}$ We measure the predictive power of these simulations with the $\mathrm{R}^{2}$ from regressions of the baseline aid values against their simulated values under simplification.

While the $\mathrm{R}^{2}$ communicates the proportion of the variation in aid that can be attributed to each set of variables, it does not tell us who wins and who loses. We therefore plot gains and losses against families’ financial resources. As our measure of financial resources, we will primarily use the aid system’s current summary statistic for a family’s ability to pay for college, the expected family contribution (EFC). If our simulations reproduce the current distribution of aid across the EFC, then we

\footnotetext{
${ }^{8}$ In a small proportion of cases we exactly replicate the EFC but not the Pell Grant. This may reflect overrides of the formula at the discretion of financial aid administrators or data perturbations introduced by the Department of Education to protect data confidentiality.

${ }^{9}$ We are not the first to estimate the predictive power of individual FAFSA items on student aid. Kane (1995) notes that most of the variation in Pell Grants can be explained using just a few variables. Stoll and Stedman (2004) use student-level FAFSA data (from the 1999-2000 NPSAS) to simulate the effect on the EFC of excluding items from the aid calculation.

${ }^{10}$ We have also tested setting excluded values to their means or medians, with substantively similar results. For state of residence and elder parent's age, which are excluded from some simulations, a value of zero is not meaningful, so we assign to all applicants the default values that the aid formula imputes when these items are missing from a FAFSA.
} 
have successfully reproduced the current system's distributional priorities. We will also use adjusted gross income, a more familiar metric for financial resources, for some of our graphs.

\section{How is Targeting Affected When we Discard $80 \%$ of the FAFSA?}

We start by eliminating all of the data used in the aid calculation except for adjusted gross income of the parents (or independent students and their spouses), dependent students' earnings, parents' and students' assets, parents' and students' marital status, family size and number of family members in college. This approach (Simulation A) discards parents' and student's taxes paid, the types of income tax forms filed and the required “worksheets” (reproduced in Appendix) that elicit information about transfer income (such as the EITC, welfare, and Social Security) and other income (child support). These worksheets account for 45 of the 70 financial questions used in the calculation of aid. Using only the items in Simulation A would cut the number of financial questions on the FAFSA by more than 80 percent.

With this substantial reduction in complexity, Pell Grant eligibility changes by less than $\$ 100$ for 76 percent of aid applicants. The subsidized loan offer changes by less than $\$ 100$ for 84 percent of aid applicants. The correlation between the existing Pell and the simulated Pell is 0.95, and that between the existing and simulated subsidized loan is 0.91 . This reduction in complexity has a small impact on program costs, with the average Pell dropping by $\$ 14$ (less than one percent). All of this decrease in the Pell occurs among families with income over \$30,000; families with lower incomes actually see an increase in their grants (see Figure 2). Loans decrease more substantially, by an average of $\$ 215$, or seven percent, with the decrease concentrated among families with incomes between $\$ 55,000$ and $\$ 75,000$.

Why are we able to throw out so much information about applicants, with relatively little consequence for their aid eligibility? First, many of the data items on the FAFSA are relevant to very few families (e.g., living stipends for the military and clergy, foreign income); that is, while these items affect eligibility, they are non-zero for a small number of people. Second, some of the items are common, but only at the top or bottom of the income distribution (e.g., IRA rollovers and welfare benefits). Those at the top or bottom of the income distribution qualify for no aid or the maximum of aid solely on the basis 
of their income, rendering additional information about their financial situation irrelevant. If we know that a family of four earns $\$ 20,000$ a year, we also know the family is eligible for the Pell Grant and information about the family’s Food Stamps, medical expenses and welfare benefits is redundant. Similarly, if a family of three earns $\$ 100,000$ a year, then information about the family’s $401(\mathrm{k})$ investments, financial assets, and business income is redundant.

It is clear in Figure 2 that this particular approach affects the distribution of loans more than that of grants. Why is this true? Subsidized loan eligibility is based on the same measure of ability to pay (the EFC) as Pell Grants. Therefore, any simplification that exactly preserves the EFC will preserve both Pell Grant and subsidized loan amounts. However, slight changes in EFCs that have no implication for Pell Grants can have implications for student loan eligibility. This is because many families who are nowhere near the threshold for Pell receipt are on the margin of receiving a larger (or smaller) subsidized loan. Lower- and middle-income families often have EFCs well below their total cost of attendance and thus qualify for the maximum loans regardless of small changes in their EFCs. But such small changes can affect upper-income families, whose EFCs may be just above or below their cost of attendance.

\section{How is Targeting Affected When We Disregard Assets?}

We next discard parents' and student’s assets from the calculation of aid (Simulation B). The "taxation” of assets by the aid formula has been roundly criticized by economists. Economists (e.g., Edlin, 1993 and Feldstein, 1995) have argued that the taxation of assets by the aid formula creates horizontal inequities: identical families with identical lifetime earnings can be treated very differently by the aid system, with aid reduced for the family that has sacrificed consumption in order to save for college.

In practical terms, assets have little impact on the calculation of federal aid. When we drop all assets from the aid formula, 75 percent of applicants experience a change of less than $\$ 100$ in their Pell Grant. Thirteen percent see a change of more than \$500 in their Pell. Excluding assets increases the average Pell at low levels of income (Figure 3). Total Pell expenditures in this simulation increase by just 3.3 percent over their current level, by an average of \$54 per applicant. Student loan offers drop slightly (relative to their current level) using this approach, by 4.2 percent. The decrease in eligibility is again 
concentrated among families with incomes over \$60,000. For 84 percent of applicants, subsidized loan eligibility changes by less than $\$ 100$.

Assets have so little effect on aid eligibility because few households have assets that are "taxed" by the aid formula. Families hold the vast majority of their wealth in homes and retirement funds, both of which are protected by the aid formula. Other financial assets count only if they are above a threshold that increases with the age of the parents (up to \$54,500). Among dependent students who file a FAFSA, 85 percent have no assets above the disregard. Among those from families with income below $\$ 50,000$, it's 93 percent. ${ }^{11}$ As a result, for the overwhelmingly majority of families the effective tax rate on assets is already zero. $^{12}$

It could be the case, however, that families with substantial assets simply do not file a FAFSA, since they know they will not be eligible for aid. In this case, the students filing a FAFSA would be unrepresentative of the entire population of college students. We can check on this by comparing assets of current FAFSA applicants to assets of all households with similar incomes. We do so using data from the 2004 Survey of Consumer Finances, focusing on households that contain children and have income of below $\$ 50,000$ (the effective income cap for Pell eligibility). Among all such households, the $50^{\text {th }}$ percentile of non-retirement financial assets is below $\$ 1000$ and the $95^{\text {th }}$ percentile is below $\$ 40,000 .{ }^{13}$ The analogous figures for dependent Pell recipients in NPSAS:04 are quite similar: \$200 and \$31,000. ${ }^{14}$

These figures indicate that the assets of households currently applying for aid are quite similar to the population that could apply for aid. These statistics offer no support for the concern that a substantial population of low-income, high-asset families will gain Pell eligibility if assets are completely removed from taxation. This is not to say that there no such families will gain eligibility: under this simulation, 0.65 percent of Pell recipients have more than $\$ 250,000$ in assets. These families would receive a combined \$42.5 million in Pell Grants. While the existence of such “wrongful recipients” can be

\footnotetext{
${ }^{11}$ Authors' calculations from NPSAS:04.

${ }^{12}$ For 99 percent of aid applicants, the marginal tax rate on assets is zero. We obtain this figure by adding $\$ 100$ to every applicant's financial assets and recalculating aid. For 99 percent of the sample, Pell eligibility is unchanged. ${ }^{13}$ Authors' calculations from the 2004 Survey of Consumer Finances. Figure is for households with children and incomes below $\$ 50,000$. The $99^{\text {th }}$ percentile of financial, non-retirement assets for this population is roughly $\$ 160,000$.

${ }^{14}$ The $99^{\text {th }}$ percentiles of non-retirement financial assets for dependent and independent Pell recipients are $\$ 95,000$ and $\$ 13,000$, respectively.
} 
politically challenging, they represent only a very small fraction of total program expenditures. This political cost and increase in expenditures should be weighed again the implied reduction in complexity for the other 99.35 percent of aid applicants.

\section{How is Targeting Affected When We Disregard Dependent Students' Earnings?}

The aid formula taxes student earnings (over an income protection allowance of \$2,550) at a rate of fifty percent. ${ }^{15}$ Variation in students' earnings is driven predominantly by work hours, rather than variation in hourly wages. As a result, this is primarily a tax on students' work effort. The tax falls more heavily on low-income households, since both student work hours and earnings drop as parental income rises. While 73 percent of dependent students from lower-income families have positive earnings, the figure is 62 percent for students from upper-income families. ${ }^{16}$ Median student earnings are $\$ 2,730$ for the lower-income group, as compared to $\$ 2,231$ for the upper income group.

When we exclude the earnings of dependent students from the calculation of aid eligibility (Simulation C), the Pell Grants of seventy-two percent of aid applicants are essentially unchanged, while the subsidized loans of 84 percent of applicants are unchanged. The correlation of this simulated Pell grant with the current Pell grant is 0.92; the analogous correlation for the subsidized loan is 0.90 . In Figure 4, we plot the associated changes in Pell Grant and subsidized loan eligibility against income. Since discarding dependent students’ earnings mechanically increases calculated need, three times as many applicants would see a significant increase (\$500 or more) in Pell eligibility as would see a significant decrease. Pell Grants increase most for those whose parents earn between \$15,000 and \$40,000 per year. This the most expensive approach so far discussed, with average Pell Grants increasing by $\$ 185$ per applicant (11.5 percent); grants change only for dependent students (for independent students, approaches B and C are equivalent). Loans are relatively unaffected by this approach, with the average offer dropping by about one percent, or $\$ 39$.

\footnotetext{
${ }^{15}$ In 2007-2008, the disregard will rise to \$3,000 and the tax rate will fall to 35 percent. Students also receive allowances for federal taxes paid and an estimate of state taxes paid. If parents' total allowances exceed parents’ income, the excess parents' allowance is used to protect more of the student's income.

${ }^{16}$ We divide families at the rough median of household income, $\$ 50,000$.
} 
This last approach limits the data required to calculate aid items to income, marital status, family size, and number of family members in college. For younger, dependent students, these data items reflect the income and characteristics of their parents' household. For older students who have their own households, these data items reflect the income and characteristics of their own household. Most of these data items are already collected in income tax returns, a point to which we will return later in the paper.

\section{A Quantitative Analysis of the Costs of Complexity}

The previous section showed that the benefits of complexity are quite small. What are its costs? We posited earlier in the paper that complexity and uncertainty in traditional student aid may blunt its ability to influence schooling decisions. In this section, we flesh out this hypothesis, borrowing insights from economic theory and evidence. Both classical and behavioral economics offer useful insights into the effect of complexity in aid on schooling decisions. The classical model highlights the transaction costs of applying for aid (primarily time costs), which reduce the net value of aid to potential students. For students on the margin of college, these additional transactions costs may tip the cost-benefit calculation against college enrollment. Behavioral economics suggests that complexity in aid could discourage a student from attending college even if a rational calculation of schooling costs and benefits would suggest that college was the optimal choice.

\section{A Rational Perspective on the Effect of Complexity in Student Aid on Schooling Decisions}

In the human capital model, individuals weigh the present costs of schooling against its future benefits. Costs include opportunity costs (forgone earnings) and direct costs (tuition and fees). For some students, these costs will be partially offset by financial aid. The value of any such aid in turn, is reduced by the opportunity cost of the time required to obtain the aid. From a rational perspective, then, the pertinent question is whether the costs of applying for aid plausibly outweigh its expected value. If the costs of aid outweigh its benefits for those on the margin of college, then this would explain why federal aid has little effect on schooling decisions. 
What are the costs of applying for aid? Costs include the time needed to read the documents, understand the rules, collect the required documents, and to fill out the form. How long does this process take? The Department of Education estimates that this entire process takes one hour, which strikes us as implausible. Reading the instructions would take twenty minutes for a typical adult reading at a speed of 300 words per minute. ${ }^{17}$ This would leave 40 minutes for applicants to actually answer the 127 questions on the FAFSA, requiring the peppy pace of three questions per minute. In the remainder of this section, we examine the questions asked on the FAFSA in order to get a sense of the burden they place on applicants, especially low-income applicants.

All questions on the FAFSA are not created equal; some require considerably less time than other. For some, little thought is required; for example, 55 questions ask essentially for identifying or demographic information. While the remaining 72 questions do ask about finances, families with uncomplicated lives can skip through some of them quickly. For example, never-divorced parents can rapidly move through questions about child support.

Other questions can be answered quickly if an applicant and her parents have already completed their federal tax returns. About 30 financial items required for an EFC calculation for dependent students refer to lines on the 1040, and so fall into this category. However, about half of first-year, dependent applicants had not yet filed all their federal tax forms by the time they had submitted their FAFSA in 2003. ${ }^{18}$ This is likely because schools urge applicants to file the FAFSA early so that they do not miss a chance to access limited aid funds. ${ }^{19}$ In fact, the FAFSA itself prominently lists 13 states that have aid application deadline that precede the April 15 tax deadline. Aid applicants who have not yet filed taxes have to amend their FAFSAs once they file, adding to their time costs.

\footnotetext{
${ }^{17}$ See Nuttall (1996) on average reading speeds. The FAFSA questionnaire and instructions contain about 6,000 words.

${ }^{18}$ Authors' calculations from NPSAS:04. This includes those who have not yet filed both the parent's and student's tax form and those that do not plan to file income taxes.

${ }^{19}$ Nine percent of FAFSA applicants file in January, before households have even received their W-2 forms and other end-of-year tax documents. This time pattern of FAFSA filing is driven by the deadlines of individual schools and states, some of which request that the FAFSA be submitted by the first of January or February. For example, Michigan State University: "As soon as possible after the January 1 preceding your fall semester, file the FAFSA. If you or your parents haven't filed taxes yet, use estimated data on the FAFSA and correct it later if necessary. " http://finaid.msu.edu/fa101.asp Students are commonly warned that delaying submission of the FAFSA may threaten their access to limited student aid funds.
} 
For those who have completed their federal taxes, and so can answer tax-related questions quickly, there still remain the FAFSA items that do not correspond to items on tax returns. Table 3 lists some data items queried by the FAFSA but not the 1040. Several are open-ended, and require calculation or record-searching on the part of the applicant:

"As of today, what is the net worth of your (and spouse's) investments, including real estate (not your home)? Net worth means current value minus debt."

"As of today, what is your (and spouse's) total current balance of cash, checking and savings accounts?"

"Other untaxed income not reported elsewhere on Worksheets A and B (e.g. worker's compensation, untaxed portions of railroad retirement benefits, Black Lung benefits, disability, combat pay not reported on the tax return, etc.)? Don't include student aid, Workforce Investment Act educational benefits, non-tax filers' combat pay, or benefits from flexible spending arrangements, e.g. cafeteria plans."

It seems unlikely that such questions could be answered in twenty seconds.

Table 3 shows that once families have completed their tax forms, they still face quite a bit more work. This is true for low-income families as well as upper-income families. In fact, six of the questions in Table 3 apply primarily to low-income families (e.g., welfare benefits) while seven apply to families of any income level (e.g., child support, checking account balances). Only two apply primarily to upperincome families (business holdings and 401(k) contributions).

What is a reasonable estimate of the average time required to complete a FAFSA? We showed in Table 1 that the FAFSA is comparable in length to a 1040, which the IRS estimates takes 16 hours to complete. The shorter 1040A and 1040EZ are estimated to require 13 and eight hours, respectively. Blumenthal and Slemrod (1992), based on their own survey data, conclude that the time required for tax compliance averages 27 hours per filing household, with time estimates higher for low- and high-income households. Ten hours per family is therefore a conservative estimate of the length of time required to complete a FAFSA: longer than the IRS's estimate of the time needed for a 1040EZ, but less than their estimates for the 1040A or long form, and substantially less than the 27 hours estimated by Blumenthal and Slemrod.

Note that our ten-hour estimate is for the "typical" family. For some families, the process will be much shorter. Families that are intact, whose members have stable jobs and uncomplicated finances, and who have already filed their federal taxes, may well take less than ten hours to complete the form. Low- 
income families, the target of federal aid, tend not to fit this description. Research by Holtzblatt and McCubbin (2004) on low-income tax filers finds that such filers are more likely to have complicated living arrangements (single parents living in another family’s home) and more erratic employment patterns (multiple jobs, unemployment spells). For these families, paperwork from multiple sources may be required to complete even basic questions about employment income.

It is also likely that the length of time required to learn about and comply with any given provision of the aid process is higher for low-income families. Half of low-income high school seniors have no parent who attended college (ED 2002) and so have no experience with the aid system. ${ }^{20}$ Thirteen percent live in families in which English is not the primary language, double the rate of highincome youth (ibid). More than two-thirds of children from families with incomes below \$25,000 have no Internet access at home, compared with 12 percent of families with incomes above \$50,000 (Day, Janus, and Davis 2005). ${ }^{21}$

These time costs of applying for aid reduce the value of financial aid for applicants. At average hourly wages of $\$ 17.50$ (Bureau of Labor Statistics), ten hours "costs" a family $\$ 175$. For teenagers and low-income parents, the cost is lower than this average: median earnings for a high school graduate are roughly $\$ 20,000$. Even if an aid application takes 20 hours for these families, this reduces the value of aid by only about $\$ 200$.

Even a FAFSA that required many nights to complete would still be worthwhile, from a rational perspective. Across all undergraduate aid applicants, the average Pell Grant in 2003-04 was approximately $\$ 1,100$, handily outweighing the time costs just described. ${ }^{22}$ Further, the returns to a college education dwarf any reasonable estimate of the costs of applying for aid. Barrow and Rouse (2005) estimate that getting a college degree is equivalent to a $\$ 300,000$ windfall—and this is a net benefit, after subtracting out tuition costs and wages foregone while enrolled. Any rational individual deterred from going to college by transaction costs of the magnitude described so far could only have a

\footnotetext{
${ }^{20}$ Authors' calculations, comparing families with income below $\$ 25,000$ to those with income above $\$ 50,000$.

${ }^{21}$ Authors' calculations using published tables from the computer and internet supplement to the Current Population Survey (Day, Janus, and Davis 2005).

${ }^{22}$ Authors' calculations using NPSAS:04. Only undergraduates are eligible for Pell Grants.
} 
very low expected return to college. If this is the case, then the welfare losses produced by this person failing to go to college are quite small.

\section{A Behavioral Perspective on the Effect of Complexity in Student Aid on Schooling Decisions}

A rational calculation of transaction costs did not get us far in explaining the null impact of federal aid on schooling decisions. But a growing body of economic research has shown that individual decisions depart systematically from rationality, particularly in settings in which present sacrifice is required in order to access future gains. Savings behavior has received particular attention from behavioral economists. From a rational perspective, people should save for retirement. Non-savers agree with this rational perspective: repeated surveys show non-savers stating that saving is important and that they want to save. Similarly, survey data show that an overwhelming majority of low-income high school students believe that college is important, and that they intend to go. The analogy between saving and schooling is apt: both are capital-building endeavors that require current sacrifice in pursuit of future gain.

Kahneman and Tversky (2000) argue that people are typically loss averse: they avoid worthwhile bets because "losses weigh more heavily than gains." That is, a dollar lost decreases utility more than a dollar gained increases it. When gains that are probable but losses are certain, this will lead to risk aversion and avoidance of even "good bets." Certain costs and probable gains characterize savings and college. Savers must give up consumption now in hopes of positive market returns and a long enough life to enjoy the proceeds during retirement. Students must apply for aid, give up earnings, pay tuition, and study now in hopes of an uncertain payoff in the labor market. Like retirement savings, college is a good bet, but there is enormous variance in returns. For some, college will not pay off, and this possibility may weigh heavily in schooling decisions due to loss aversion.

Behavioral economists have also concluded that people's choices are strongly influenced by the default provided them (Samuelson and Zeckhauser 1988). This tendency can cause small bureaucratic details to have a disproportionate impact upon behavior. The best evidence on this comes from the studies of the defaults presented to employees in making choices about their retirement savings. At one large financial services firm, the default choice was non-participation in the employer 401(k). New employees 
could check a box on a form to initiate automatic payroll withdrawal; not checking the box (that is, the default) led to non-participation. The company then altered the default, with non-participation requiring that the employee check a box on a form. This tiny change increased 401(k) participation by 50 percentage points (Madrian and Shea, 2001). No rational calculation of transaction costs would predict this sort of effect.

While there is scant empirical research specifically relating behavioral phenomena to college decision-making, it is pretty safe to conclude that teenagers are not more rational than adults. The timeinconsistent preferences that appear to undermine saving among adults also fit the behavior of lowincome teenagers. In a project that tracked low-income youth as they made their schooling decisions, researchers found that few made a deliberate choice to not to go to college (Avery and Kane, 2004). Rather, they missed a key deadline, or incorrectly filled out a form, or failed to take a required class, and thereby fell off the path to college; that is, seemingly minor obstacles put youth off the path to college.

Defaults appear to particularly affect the behavior of these teenagers. For upper-income teenagers, the affirmative actions of their parents and schools establish college entry as the "default" path. Their high schools guide them through the multiple steps and deadlines of the college and financial aid process. Informal guidance and support is also provided by their college-educated relatives and neighbors, who act as de facto guidance counselors. By contrast, due to their comparatively weak institutional and social supports, the default option for low-income students is to not go to college. Lower-income schools receive fewer visits from college representatives and have fewer guidance counselors per student. Parents and siblings are not as likely to have gone to college, and so cannot compensate for this lack of institutional support.

\section{Weighing the Costs and Benefits of Complexity in Student Aid}

On net, the evidence just discussed is intriguing but speculative. We have calculated that the time cost of completing aid forms is roughly \$2 billion a year, or about \$200 per application. From a rational perspective, these costs are unlikely to prevent a student from applying for a grant whose average value is over \$1000. But behavioral economics predicts that complexity will discourage students from utilizing 
aid; quasi-experimental evidence shows that complexity affects behavior in a different but related arena (retirement savings); and observational studies show that high many school students who intend to go to college get tripped up by seemingly minor obstacles. This body of evidence comprises a strong but not dispositive case that complexity may well blunt the effect of aid. ${ }^{23}$ We have further shown that the benefits of this complexity are conclusively quite small: complexity contributes little to the targeting of aid.

The balance tips further against complexity when we consider the administrative costs it imposes on colleges and governments. We have so far calculated only the costs of complexity that are borne by applicants, since these are costs that plausibly could explain null effect of federal aid on schooling decisions. While administrative costs do not affect the schooling decisions of individuals, they do belong in any social welfare calculation of the costs and benefits of complexity in aid. We therefore now examine these administrative costs.

Financial costs to the government of administering the aid-eligibility process are small relative to the volume of aid delivered annually: about \$220 million. While this figure is low, it is because the administrative costs have been shifted to colleges, who are responsible for answering students' questions, packaging and disbursing federal student aid, and "verifying” aid applications. Verification is a cumbersome process in which financial aid administrators audit aid applications. Schools are statutorily required to audit 30 percent of aid applications, and some audit all applications. At least 3 million such audits take place each year. ${ }^{24}$ By comparison, the IRS audit rate is 1.5 percent, implying that 2 million IRS audits take place annually. ${ }^{25}$

Staff paid by the colleges are responsible for all of these tasks, which they must undertake in accordance with the 225-page Federal Student Aid Handbook. A survey of 650 institutions by the

\footnotetext{
${ }^{23}$ An ongoing experiment on the deterrent effects of complexity on the FAFSA will provide solid evidence in this area. Eric Bettinger, Bridget Terry Long, and Phil Oreopolous have partnered with H\&R Block to pre-fill the FAFSA and provide projected financial aid estimates to randomly-selected individuals who utilized H\&R Block's tax preparation services. College enrollment data for the treatment and control groups will then be collected from administrative records.

${ }^{24}$ A survey by the National Association of Student Financial Aid Administrators found that schools audit 40 percent of aid applications; one in ten schools audit all applications. Williams (2006).

${ }^{25}$ Although the Department of Education states that FAAs do not need to be "tax experts," they "must have a fundamental understanding of relevant tax issues that can considerably affect the need analysis" (ED, 2005b; p. 101). For example, if a student's parents divorced after filing their taxes, the FAA may need to recalculate the relevant parent's taxes as if he or she had filed as a single individual.
} 
National Association of Financial Aid Administrators (NASFAA) found that financial aid offices on average employed nine full-time staff members (Williams, 2006). Using salary estimates from the same organization (Williams 2004), the 6,444 institutions eligible for federal aid would spend a total of \$2.1 billion on salaries for full-time financial aid professionals. ${ }^{26}$ Overhead and benefits would add further to these costs. To help pay colleges' administrative costs, the Department of Education allocated to schools administrative allowances of $\$ 83.4$ million in 2005 . However, the annual cost of required audits alone is estimated at \$432 million (Advisory Committee on Student Financial Assistance, 2005).

The true administrative cost of complexity may be somewhat higher or lower than our combined estimate of $\$ 2.3$ billion (for schools and the federal government). On the one hand, reducing complexity is not likely to completely eliminate the need for financial aid professionals. Even with a much simpler application, some staff will still be needed to answer questions and disburse aid. On the other hand, this estimate does not include the cost of financial aid-related computer software or printing and distributing financial aid-related materials.

These administrative costs, along with cost of time applicants spend completing the FAFSA, constitute a lower bound on the cost of complexity in student aid: perhaps $\$ 4$ billion dollars a year. The upper bound is blurrier: at worst, complexity in aid discourages from attending college the very population it targets for assistance.

\section{Discussion}

The key variables that predict aid -- income and family composition -- are currently collected in federal income tax returns. In principle, then, the aid application could be eliminated altogether and eligibility for student aid determined using data already collected by the IRS. Families could apply for a grant by checking off a box on their income tax form, instructing IRS to forward applicants' adjusted gross income, dependency status, and number of dependents to the Department of Education. This would eliminate the time costs of applying for aid, saving \$2 billion in hours currently lost to filling out aid

\footnotetext{
${ }^{26}$ Estimates assume each office employs one director at \$62,000, one assistant director at \$44,000, 2.5 officers at $\$ 35,000$ each, 1.3 clerical staff at $\$ 29,000$ each and three other staff members at $\$ 30,000$ each. Salary estimates are from Williams (2004) and are inflated to 2006 dollars.
} 
forms. Further, if income information came directly to the Department of Education from the IRS, rather than from self-reports on a FAFSA, schools would no longer need to audit three million applications a year. Every application would effectively be "audited," since the data generating eligibility would come directly from IRS.

This approach would be similar in spirit to a "no-return" tax system, in which tax authorities use data they already have collected to determine tax liability. As of 1996, 36 countries had instituted such approaches (Government Accounting Office, 1996). Gale and Holtzblatt (1997) discuss several such programs. Most relevant to the current context are the "tax agency reconciliation" systems of Denmark and Sweden, in which, at the taxpayer's request, the taxing authority generates a return based on income data already collected by the government. The taxpayer approves or disputes the return, and then refunds or payments are made. An analogous approach would have aid applicants indicate to the Department of Education their desire to make an aid application. ED could then generate an application based on income data held by IRS, most practically from the previous tax year.

As in the current system, eligibility for the 2006-07 academic year could be based on 2005 income, as reported to the IRS in early 2006. A potential logistical hurdle is that the IRS is not able to confirm income data immediately upon receiving an income tax return. In this case, eligibility could be based on income from a previous tax year. Because the IRS can provide transcripts of up to three years of prior taxes (and does so for thousands of “no paperwork” mortgage applications each year), eligibility could even be based on an average of several prior years of income. This approach would have other useful properties. It would reduce the incentive to shift income between years in order to avoid taxation of a single year's income by the aid formula. Several years of income are also a better measure of permanent income than a single year (Edlin, 1995).

A potentially more powerful advantage is that a simplified aid formula would enable families to easily determine their eligibility well before their child applies to college. If aid eligibility were determined by just a couple of data items, such as income and family size, aid could be described in a lookup table simple enough to put on a poster that could hang in a high school hallway. The federal government could also proactively mail financial aid estimates to taxpayers, much as the Social Security 
Administration now mails out annual benefit estimates. Such early information may help people to make better-informed decisions about their long-term investments. High school students of all income levels overestimate the cost of college. But while high-income students express confidence that they will find a way to pay, low-income students are pessimistic about their ability to pay for college (Avery and Kane, 2004). Spring of senior year, when information about aid eligibility currently arrives, is when many students decide which college to attend. It is unlikely that many students make their decision about whether to attend college this late in the game. Information about aid could affect these decisions if they understood their aid options earlier.

We should note that there have been several efforts to simplify the FAFSA. In 1986, Congress mandated an “automatic zero" EFC for families with taxable income below \$15,000 who are also eligible to file an IRS Form 1040A or 1040EZ. These applicants are legally allowed to skip more than 50 of the over 70 financial questions on the FAFSA. Congress also mandated a "simplified needs test" for families earning less than $\$ 50,000$ who are eligible to file the 1040A or 1040EZ; for these families, asset information can be disregarded. These efforts do not appear to have simplified the aid application process. Among those who had their FAFSA processed using the simplified needs test and who were eligible to skip the asset questions, 48 percent provided asset information. Among those who had their application processed under the automatic-zero EFC formula, 90 percent responded to questions that they were not required to answer. For example, 63 percent completed at least part of Worksheet A and 30 percent reported non-zero assets. ${ }^{27}$

Why do aid applicants answer questions they don't have to answer? First, the option to skip questions is poorly communicated. Approved shortcuts are never mentioned on the paper FAFSA, filled out by about half of dependent, undergraduate applicants with incomes below $\$ 50,000{ }^{28}$ The option to skip questions is mentioned only midway through the online version of the FAFSA. Since families are instructed to prepare for the online application by filling out printed worksheets that never mention the option to skip questions, they are likely to have already gathered the requisite data (or given up on the application) by the time they reach the option to skip a question. Second, when are offered the option to

\footnotetext{
${ }^{27}$ Authors' calculations from NPSAS:04.

${ }^{28}$ Authors' calculations from NPSAS:04.
} 
skip a question on the online FAFSA, they are warned that doing so may threaten their eligibility for state- or school-administered aid (U.S. Department of Education, 2005c).

These failed attempts point to the limits of technology as a tool for simplifying the aid application (and highlight the potential value of eliminating the application altogether). Goolsbee (2004) discusses the limits of technology as a solution to complexity in the tax code. He points out that those who readily adopt new technologies (such as tax preparation software or, in the present case, the online FAFSA) are not likely those who are most burdened by the current system. After examining the characteristics of those who do and do not use tax preparation software, Goolsbee concludes that the use of the software is determined not by the complexity faced by the filer but by her costs of adopting the new technology. Those who use tax software do not have particularly complicated tax situations, but instead they are more likely to be well-educated and use computers in other parts of their lives. That is, those who are at ease with technology are the ones who tend to adopt it.

An examination of the demographics of those who file the FAFSA online suggests that the same holds in the present setting (see Table 4). About 57 percent of first-time freshman filed online in 2003. The median income of these online filers is $\$ 45,636$, while that of paper filers is $\$ 27,332$. The median Pell Grant of web filers is zero, while that of paper filers is $\$ 1,600$. Those who avoid the online FAFSA are disproportionately nonwhite, with parents who did not go to college and who do not speak English as a first language. These statistics show that the paper FAFSA is the most relevant application for the populations whose low college attendance rates are cited in support of increased spending on federal aid for college. The statistics in Table 4 indicate that low-income, nonwhite, first-generation college entrants, disproportionately enter the aid system via the paper FAFSA. Technological solutions to complexity that rely on the web FAFSA will leave the application experience of nearly half of these students unaffected.

\section{Conclusion}

Complexity in the federal tax code has received considerable attention from economists and been the focus of reform efforts for decades. In contrast, complexity in financial aid has received little attention. As college attendance rates rise, the burden the aid process imposes on families is of increasing 
policy relevance. Even moderate compliance costs create substantial costs to the economy when summed over the ten million households that apply for aid each year. Further, complexity in the aid process may undermine the efficacy of aid in achieving its purpose, which is to make college an option for those who could not otherwise afford to attend. If complexity burdens those on the margin of college entry, it could well blunt the impact of aid on their schooling decisions.

We have used the perspectives of both classical and behavioral economics to examine the costs of complexity in student financial aid. Relative to our previous work (Dynarski and Scott-Clayton, 2006 and 2007), we have explored several new areas. We have shown that complexity does little to improve targeting of either Pell Grants or Stafford subsidized loans. Since loans now comprise the bulk of federal aid, this finding is particularly important. Further, our analysis of grant and loan eligibility considers dependent as well as independent students, each of which account for about half of the undergraduate population. Extending the analysis to include independent students does not affect our conclusion that complexity in the aid process does little to improve targeting.

We have also provided a detailed discussion of the time costs of completing the FAFSA, focusing in particular on the marginal effort required to complete the FAFSA once a household has filed its federal tax return. We conclude that while the time cost of the FAFSA likely varies considerably across households, the Department of Education's estimate of one hour is a gross understatement. Given the length and complexity of the FAFSA, which approaches that of an IRS 1040, we conclude that ten hours is a more reasonable estimate. Ten hours is less than the 16 hours the IRS estimates is required for a 1040, which we show is similar in length to a FAFSA.

We estimate that the financial cost of complexity is at least four billion dollars a year, including time costs of completing the FAFSA ( $\$ 1.75$ billion) and salaries for college staff who administer aid based on the federal formula (\$2 billion). Colleges carry out much of the work involved in determining aid eligibility, including three million audits of FAFSAs each year. These audits are in response to a federal mandate that directs each college to audit thirty percent of its aid applicants, dwarfing the IRS audit rate of 1.5 percent. 
The costs of complexity are difficult to measure precisely, but we have shown that the benefits are clearly miniscule. Much of the complexity in the aid system does little to improve the targeting of aid. The items that we find drive eligibility for loans and grants —adjusted gross income and family size—are already collected via income tax forms. Aid eligibility could therefore be determined using existing tax information, and the aid application could be eliminated. This approach is similar in spirit to a "no-return" tax system, in which tax authorities use data they already have collected to determine tax liability (Government Accounting Office, 1996; Gale and Holtzblatt, 1997).

A key lesson of our research is that we can substantially reduce complexity and uncertainty in the aid system if we are willing to tolerate minor imperfections in measuring ability to pay. At a minimum, a simpler aid program would increase the efficiency of aid dollars by reducing the administrative and paperwork costs for schools and families. At best, simplification would clarify incentives for students and induce into college some who now believe it is unaffordable. 


\section{References}

Abraham, Katharine and Melissa Clark (2006). "Financial Aid and Students' College Decisions Evidence from the District of Columbia Tuition Assistance Grant Program" Journal of Human Resources 41(3), pp. 578-610.

Advisory Committee on Student Financial Assistance. “The Student Aid Gauntlet: Making Access to College Simple and Certain: Final Report of the Special Study of Simplification of Need Analysis and Application for Title IV Aid.” Washington, D.C.: Advisory Committee on Student Financial Assistance (January 23, 2005). URL: http://www.ed.gov/about/bdscomm/list/acsfa/edlitegauntlet.html

Akerlof, George A. "The Economics of 'Tagging' as Applied to the Optimal Income Tax, Welfare Programs, and Manpower Planning.” American Economic Review 68, no. 1 (March 1978): 8-19.

Avery, Christopher and Thomas J. Kane. "Student Perceptions of College Opportunities: The Boston COACH Program.” In College Choices: The Economics of Where to Go, When to Go, and How To Pay for It, edited by Caroline Hoxby, 355-394. Chicago: University of Chicago Press, 2004.

Barrow, Lisa and Cecilia Elena Rouse. “Does College Still Pay?” The Economists’ Voice v. 2, no. 4 (2005).

Bertrand, Marianne, Erzo F. P. Luttmer, and Sendhil Mullainathan. "Network Effects and Welfare Cultures.” Quarterly Journal of Economics 115, no. 3 (August 2000): 1019-1055.

Bertrand, Marianne, Sendhil Mullainathan, and Eldar Shafir. “A Behavioral-Economics View of Poverty.” American Economic Review 94, no. 2 (May 2004): 419-423.

Berube, Alan, Anne Kim, Benjamin Forman, and Megan Burns. "The Price of Paying Taxes: How Tax Preparation and Refund Loan Fees Erode the Benefits of the EITC." Washington, D.C.: Brookings Institution, Progressive Policy Institute Survey Series (May 2002). URL: http://www.brookings.edu/metro/publications/berubekimeitcexsum.html.

Bettinger, Eric. "How Financial Aid Affects Persistence," In College Choices: The Economics of Where to Go, When to Go, and How To Pay for It, edited by Caroline Hoxby, 207-238. Chicago: University of Chicago Press, 2004.

Blumenthal, Marsha and Joel Slemrod. "The Compliance Cost of the U.S. Individual Income Tax System: A Second Look After Tax Reform.” National Tax Journal 45, no. 2 (June 1992): 185-202.

College Board. Trends in Student Aid 1998. New York: College Board Publications, 1998.

College Board. Education Pays. New York: College Board Publications, 2004.

College Board. Trends in Student Aid 2005. New York: College Board Publications, 2005. 
College Board. Trends in College Pricing 2006. New York: College Board Publications, 2006.

Currie, Janet. “The take up of social benefits.” NBER Working Paper No. 10488. Cambridge, MA: National Bureau of Economic Research (2004).

Duffy, Elizabeth and Idana Goldberg. Crafting a Class: College Admissions and Financial Aid, 19551994. Ewing, NJ: Princeton University Press, 1998.

Duflo, Esther, and Emmanuel Saez. "The Role of Information and Social Interactions in Retirement Plan Decisions: Evidence from a Randomized Experiment.” Quarterly Journal of Economics 118 No. 3 (August, 2003): 815-842.

Dynarski, Susan M. "Hope for Whom? Financial Aid for the Middle Class and Its Impact on College Attendance.” National Tax Journal 53, no. 3 (Part 2 Sept. 2000): 629-661.

Dynarski, Susan M. "Does Aid Matter? Measuring the Effect of Student Aid on College Attendance and Completion.” American Economic Review 93, no. 1 (March 2003): 279-288.

Dynarski, Susan M. “The New Merit Aid.” In College Choices: The Economics of Where to Go, When to Go, and How to Pay for It, edited by Caroline Hoxby. Chicago: University of Chicago Press, 2004a.

Dynarski, Susan M. “Tax policy and education policy: Collision or coordination?” In Tax Policy and the Economy, edited by James M. Poterba. Cambridge, MA: MIT Press, 2004b.

Dynarski, Susan M., and Judith E. Scott-Clayton. 2006. The cost of complexity in federal student aid: Lessons from optimal tax theory and behavioral economics. National Tax Journal 59 (2): 319-56.

Dynarski, Susan M., and Judith E. Scott-Clayton. 2007. "Pell Grants on a Postcard: A Proposal for Simple and Predictable Federal Student Aid.” Hamilton Project Discussion Paper.

Dynarski, Susan M. “Building the Stock of College-Educated Labor.” Journal of Human Resources (forthcoming).

Edlin, Aaron S. “Is College Financial Aid Equitable and Efficient?” Journal of Economic Perspectives 7, no. 2 (Spring 1993): 143-158.

Feldstein, Martin (1995). “Scholarship Rules and Private Savings.” American Economic Review 85:3, 552-66.

Gale, William and Janet Holtzblatt (1997). “On the Possibility of a No-Return Tax System.” National Tax Journal 50 (September): 475-85.

Goolsbee, Austan (2004). "The TurboTax Revolution? Evaluating the Ability of Technology to Solve the Tax Complexity Dilemma," in The Crisis in Tax Administration, edited by Henry Aaron and Joel Slemrod, Brookings Institution Press (Washington, D.C.), 124-137. 
Greenstein, Robert. "The Earned Income Tax Credit: Boosting Employment, Aiding the Working Poor." Washington, D.C.: Center for Budget and Policy Priorities (August 2005). URL: http://www.cbpp.org/7-19-05eic.htm

Hansen, W. Lee. “The Impact of Student Financial Aid on Access.” In The Crisis in Higher Education, edited by Joseph Froomkin. New York: Academy of Political Science, 1983.

Henry, Gary, Steve Harkreader, Philo A. Hutcheson and Craig S. Gordon (1998). "Hope Longitudinal Study, First-Year Results.” Unpublished manuscript, Georgia State University.

Holtzblatt, Janet and Janet McCubbin. "Issues Affecting Low-Income Filers,” in The Crisis in Tax Administration, edited by Henry J. Aaron and Joel Slemrod, pp. 148-200. Washington, DC: Brookings Institution Press, 2004.

Kahneman, Daniel and Amos Tversky. Choices, Values and Frames. Cambridge, MA: Cambridge University Press, 2000.

Kane, Thomas J. "Rising Public College Tuition and College Entry: How Well Do Public Subsidies Promote Access to College?” NBER Working Paper 5164, 1995.

Kane, Thomas J. “A Quasi-Experimental Estimate of the Impact of Financial Aid on College- Going.” National Bureau of Economic Research Working Paper 9703, 2003.

Kaplow, Louis. “Optimal Taxation with Costly Enforcement and Evasion.” Journal of Public Economics 43, no. 2 (November 1990): 221-236.

Kaplow, Louis. "How Tax Complexity and Enforcement Affect the Equity and Efficiency of the Income Tax.” National Tax Journal 49, no. 1 (March 1996): 135-150.

Liebman, Jeffrey. "The Impact of the Earned Income Tax Credit on Incentives and Income Distribution," Tax Policy and the Economy No. 12 (1998).

Liebman, Jeffrey and Richard Zeckhauser. "Schmeduling." Harvard University, unpublished manuscript, 2004.

Madrian, Brigitte C. and Dennis F. Shea. "The Power of Suggestion: Inertia in 401(k) Participation and Savings Behavior.” Quarterly Journal of Economics CXVI No. 4 (November 2001): 1149-1187.

Moffitt, Robert. “An Economic Model of Welfare Stigma.” American Economic Review 73 No. 5 (December 1983): 1023-1035.

Mullainathan, Sendhil, and Richard H. Thaler. "Behavioral economics.” NBER Working Paper No. 7948. Cambridge, MA: National Bureau of Economic Research (2000).

National Association of State Student Grant and Aid Programs (NASSGAP). "35th Annual Survey Report on State-Sponsored Student Financial Aid: Academic Year 2003-2004." Washington, DC: National Association of State Student Grant and Aid Programs, 2005. 
Nichols, Albert L., Richard J. Zeckhauser. "Targeting Transfers through Restrictions on Recipients.” American Economic Review 72, no. 2 (May 1982): 372-377.

Nuttall, Christine (1996). Teaching Reading Skills in a Foreign Language. Oxford: Heinemann.

O’Donoghue, Ted and Matthew Rabin. “Doing It Now or Later,” The American Economic Review, 89 \#1, March 1999, 103-124.

President's Advisory Panel on Federal Tax Reform. Final Report of the President's Advisory Panel on Federal Tax Reform. Washington, D.C.: U.S. Government Printing Office, 2005. URL: http://www.taxreformpanel.gov/final-report/.

Samuelson, William and Richard Zeckhauser. “Status quo bias in decision making.” Journal of Risk and Uncertainty 1, Issue 1, March 1988: 7-59.

Seftor, Neil and Turner, Sarah. "Back to School: Federal Student Aid Policy and Adult College Enrollment.” Journal of Human Resources 37:2 (2002): 336-352.

Social Security Administration. Social Security Bulletin Annual Statistical Supplement. Washington, DC: U.S. Government Printing Office, various years.

Stedman, J. B. Federal Pell Grant Program of the Higher Education Act: Background and Reauthorization. Congressional Research Service Report for Congress, Order Code RL31668 (2003).

Stoll, Adam, and Stedman, James B. Federal Student Aid Need Analysis: Background and Selected Simplification Issues. Congressional Research Service Report for Congress, Order Code 32083 (2004).

Thaler, Richard H. “Psychology and Savings Policies.” American Economic Review 84, no. 2 (May 1994): 186-192.

U.S. Department of Education, National Center for Education Statistics. Digest of Education Statistics. Washington, DC: U.S. Government Printing Office (1998).

U.S. Department of Education. Final Audit Report of the Student Financial Aid Application Verification Process. Control Number ED-OIG/A06-A0020. Washington, DC: U.S. Department of Education, Office of the Inspector General (2002a). URL: http://www.ed.gov/about/offices/list/oig/auditreports/a06a0020.pdf.

U.S. Department of Education. National Education Longitudinal Survey of 1988: Public-Use Data and Electronic Codebook, Base Year Through Fourth Follow-Up. Washington, DC: National Center for Education Statistics (2002b).

U.S. Department of Education. Year 2000 Performance Report and 2002 Program Annual Plan, Volume 2: Individual Programs: Student Financial Assistance. Washington, DC: U.S. Department of Education, Office of Student Financial Assistance (2002c). (URL: http://www.ed.gov/pubs/AnnualPlan2002/rV170171-SFA-0412.pdf )

U.S. Department of Education. 2003-2004 Federal Student Aid Handbook. Washington, DC: U.S. Department of Education, Office of Federal Student Aid (2003a). URL: http://ifap.ed.gov/IFAPWebApp/currentSFAHandbooksYearPag.jsp?p1=2003-2004\&p2=c 
U.S. Department of Education. 2003-2004 Free Application for Federal Student Aid. Washington, DC: U.S. Department of Education, Office of Federal Student Aid (2003b).

U.S. Department of Education. "FY 2005 ED Budget Summary: Student Financial Assistance." Washington, DC: U.S. Department of Education (February 2, 2004). URL: http://www.ed.gov/about/overview/budget/budget05/summary/edlite-section2d.html\#tables

U.S. Department of Education. 2003-2004 National Postsecondary Student Aid Survey: Restricted-Use Data and Electronic Codebook. Washington, DC: National Center for Education Statistics (2005a).

U.S. Department of Education,. 2005-2006 Federal Student Aid Handbook. Washington, DC: U.S. Department of Education, Office of Federal Student Aid (2005b). URL: http://ifap.ed.gov/IFAPWebApp/currentSFAHandbooksYearPag.jsp?p1=2005-2006\&p2=c.

U.S. Department of Education. 2006-2007 FAFSA On the Web Screenshots. Washington, DC: U.S. Department of Education, Office of Federal Student Aid (2005c). (October 2005). URL: http://ifap.ed.gov/eannouncements/1025fotwscreenshot0607.html.

U.S. Department of Education. Draft Student Aid Report 2006-2007 Washington, DC: U.S. Department of Education, Office of Federal Student Aid (2005d). URL: http://ifap.ed.gov/sarmaterials/attachments/0607DraftSAR.pdf

U.S. Department of Education. 2006-2007 Free Application for Federal Student Aid. Washington, DC: U.S. Department of Education, Office of Federal Student Aid (2006).

U.S. Government Accounting Office. Alternative Filing Systems. Washington, DC: U.S. Government Accounting Office (1996).

U.S. Government Accounting Office. Gaps in Parents' and Students' Knowledge of School Costs and Federal Aid. Washington, DC: U.S. Government Accounting Office (1990).

U.S. Office of Management and Budget. Budget of the United States Government, Fiscal Year 2005, Federal Credit Supplement. Washington, D.C., 2005. (URL: http://www.whitehouse.gov/omb/budget/fy2005/ )

Wilkinson, Rupert. Aiding Students, Buying Students. Nashville, TN: Vanderbilt University Press, 2005.

Williams, Mark S. Key Factors in Compensation of Financial Aid Administrators and Staff: A Report on the 2003 NASFAA Salary Survey. Washington, DC: National Association of Student Financial Aid Administrators, 2004.

Williams, Mark S. Key Factors in Financial Aid Office Staff Sizes: Results of the 2006 NASFAA Staffing Survey and Development of the Staffing Model. Washington, DC: National Association of Student Financial Aid Administrators, 2006. 
Table 1. Complexity of the FAFSA Versus IRS 1040

\begin{tabular}{|c|c|c|c|c|}
\hline & $\begin{array}{l}1040 \\
2005 \\
\end{array}$ & $\begin{array}{r}1040 \mathrm{~A} \\
2005 \\
\end{array}$ & $\begin{array}{r}1040 \mathrm{EZ} \\
2005 \\
\end{array}$ & $\begin{array}{r}\text { FAFSA } \\
2006-2007 \\
\end{array}$ \\
\hline Number of pages (excluding instructions) & 2 & 2 & 1 & 5 \\
\hline Total number of questions & 118 & 83 & 37 & 127 \\
\hline \multicolumn{5}{|l|}{ Non-financial items } \\
\hline Identifying information & 6 & 6 & 6 & 22 \\
\hline Demographic/family information & 8 & 8 & 2 & 18 \\
\hline Enrollment status/school info. & 0 & 0 & 0 & 7 \\
\hline Signature and preparer info. & 12 & 12 & 12 & 8 \\
\hline Other & 1 & 1 & 1 & 10 \\
\hline \multicolumn{5}{|l|}{ Financial items } \\
\hline Earned income & 1 & 1 & 1 & 5 \\
\hline Other income & 19 & 12 & 2 & 33 \\
\hline Assets & 0 & 0 & 0 & 6 \\
\hline Deductions/credits/allowances & 39 & 22 & 2 & 12 \\
\hline Tax amounts from tables, calc. lines & 21 & 12 & 6 & 6 \\
\hline Withholdings, refund preferences & 11 & 9 & 5 & 0 \\
\hline \multicolumn{5}{|l|}{ Number of items required for } \\
\hline computation of tax/refund or aid amt.* & 71 & 43 & 8 & 72 \\
\hline Length of signing statement & 49 words & 64 words & 59 words & 232 words \\
\hline Official estimate of time to prepare** & 16 hours & 13 hours & 8 hours & 1 hour \\
\hline
\end{tabular}


Table 2. Consequences of Aid Simplification

for Full-Time, Full-Year Aid Applicants

Dependent and Independent Students

\begin{tabular}{|c|c|c|c|}
\hline & $\begin{array}{r}\text { Approach A } \\
\text { Drops taxes paid, } \\
\text { type of tax form, } \\
\text { and worksheets }\end{array}$ & $\begin{array}{l}\text { Approach B } \\
\text { Additionally } \\
\text { drops assets }\end{array}$ & $\begin{array}{r}\text { Approach C } \\
\text { Additionally } \\
\text { drops dependent } \\
\text { students' earnings } \\
\end{array}$ \\
\hline \multicolumn{4}{|l|}{ Percent of applicants whose Pell... } \\
\hline ...remains the same (within $\$ 100$ ) & 0.76 & 0.75 & 0.72 \\
\hline ...increases by $\$ 500$ or more & 0.05 & 0.07 & 0.12 \\
\hline ...decreases by $\$ 500$ or more & 0.07 & 0.06 & 0.04 \\
\hline Correlation between new and old Pell Grant & 0.96 & 0.95 & 0.92 \\
\hline R-squared & 0.92 & 0.90 & 0.84 \\
\hline Change in average Pell (per full-time full-year applicant) & -13.61 & 53.79 & 185.17 \\
\hline Percentage change in total Pell program costs* & $-0.84 \%$ & $3.34 \%$ & $11.48 \%$ \\
\hline \multicolumn{4}{|l|}{ Percent of applicants whose subsidized loan offer... } \\
\hline ...remains the same (within $\$ 100$ ) & 0.84 & 0.84 & 0.84 \\
\hline ...increases by $\$ 500$ or more & 0.01 & 0.03 & 0.05 \\
\hline ...decreases by $\$ 500$ or more & 0.12 & 0.10 & 0.08 \\
\hline Correlation between new and old sub. loan offer & 0.91 & 0.90 & 0.90 \\
\hline R-squared & 0.83 & 0.81 & 0.81 \\
\hline Change in average offer (per full-time full-year applicant) & -214.86 & -126.78 & -39.49 \\
\hline Percentage change in total volume of offers** & $-7.16 \%$ & $-4.22 \%$ & $-1.31 \%$ \\
\hline \multicolumn{4}{|l|}{ Variables included in simulation: } \\
\hline Assets & $\mathrm{Y}$ & & \\
\hline Dependent students' AGI & $\mathrm{Y}$ & $\mathrm{Y}$ & \\
\hline Parental AGI, or independent student/spouse's AGI & $\mathrm{Y}$ & $\mathrm{Y}$ & $\mathrm{Y}$ \\
\hline Parental or independent students' marital status & $\mathrm{Y}$ & $\mathrm{Y}$ & $\mathrm{Y}$ \\
\hline Family size & $\mathrm{Y}$ & $\mathrm{Y}$ & $\mathrm{Y}$ \\
\hline Number of family members in coll. & $\mathrm{Y}$ & $\mathrm{Y}$ & Y \\
\hline Number of FAFSA items required for simulation & 14 & 8 & 6 \\
\hline
\end{tabular}

SOURCE: Authors' calculations using FAFSA data from NPSAS: 2003-2004. Count refers to the number of questions on the 2003-04 FAFSA required to elicit the items used in the simulated needs analysis. Count does not include questions used only to determine dependency status or questions unrelated to the calculation of need.

*Estimated total Pell expenditures for this sample of full-time, full year aid applicants are \$7.6 billion. Total Pell expenditures across all applicants were $\$ 12.7$ billion in 2003-04. 
Table 3

What Does the Aid Application Ask that the 1040 Does Not?

\begin{tabular}{|c|c|c|}
\hline & \multicolumn{2}{|c|}{ Question Typically Relevant to.. } \\
\hline & $\begin{array}{l}\text { Lower-Income } \\
\text { Families }\end{array}$ & $\begin{array}{l}\text { Upper-Income } \\
\text { Families }\end{array}$ \\
\hline $\begin{array}{l}\text { Welfare benefits, including Temporary Assistance to Needy Families (TANF). Don't include } \\
\text { food stamps or subsidized housing. }\end{array}$ & $\checkmark$ & \\
\hline $\begin{array}{l}\text { Taxable earnings from need-based employment programs, such as Federal Work-Study and } \\
\text { need-based portions of fellowships and assistantships }\end{array}$ & $\checkmark$ & \\
\hline $\begin{array}{l}\text { If you receive veteran's education benefits, for how many months from July 1, } 2006 \text { through } \\
\text { June } 30,2007 \text {, will you receive these benefits, and what amount will you receive per month? }\end{array}$ & $\checkmark$ & \\
\hline $\begin{array}{l}\text { Housing, food, and other living allowances made to members of the military, clergy and others } \\
\text { (including cash payments and cash value of benefits) }\end{array}$ & $\checkmark$ & \\
\hline $\begin{array}{l}\text { Social Security benefits received, for all household members as reported in question } 84 \text { (or } 65 \\
\text { for your parents), that were not taxed (such as SSI). }\end{array}$ & $\checkmark$ & \\
\hline $\begin{array}{l}\text { Veteran's non-education benefits such as Disability, Death Pension, or Dependency \& } \\
\text { Indemnity Compensation (DIC), and/or VA Educational Work-Study allowances }\end{array}$ & $\checkmark$ & \\
\hline $\begin{array}{l}\text { Payments to tax-deferred pension and savings plans (paid directly or withheld from earnings) } \\
\text { including, but not limited to amounts reported on the W-2 Form. }\end{array}$ & & $\checkmark$ \\
\hline $\begin{array}{l}\text { As of today, what is the net worth of your (and spouse's) current businesses and/or investment } \\
\text { farms? }\end{array}$ & & $\checkmark$ \\
\hline Student grant and scholarship aid reported to the IRS in adjusted gross income. & $\checkmark$ & $\checkmark$ \\
\hline Child support you paid because of divorce or separation or as a result of a legal requirement. & $\checkmark$ & $\checkmark$ \\
\hline Child support you received for all children. & $\checkmark$ & $\checkmark$ \\
\hline $\begin{array}{l}\text { Other untaxed income not reported elsewhere (e.g. worker's compensation, untaxed portions of } \\
\text { railroad retirement benefits, Black Lung benefits, disability, combat pay...). }\end{array}$ & $\checkmark$ & $\checkmark$ \\
\hline Money received, or paid on your behalf (e.g. bills), not reported elsewhere on this form. & $\checkmark$ & $\checkmark$ \\
\hline $\begin{array}{l}\text { As of today, what is the net worth of your (and spouse's) investments, including real estate (not } \\
\text { your home)? Net worth means current value minus debt. }\end{array}$ & $\checkmark$ & $\checkmark$ \\
\hline $\begin{array}{l}\text { As of today, what is your (and spouse's) total current balance of cash, checking and savings } \\
\text { accounts? }\end{array}$ & $\checkmark$ & $\checkmark$ \\
\hline
\end{tabular}




\section{Table 4. Applicant Characteristics by Type of FAFSA Filed First-Year Students}

\begin{tabular}{lrr}
\hline Characteristic & Paper & Web \\
\hline Percent filing each type & 42.8 & 57.2 \\
& & \\
Income & & $\$ 38,650$ \\
$\quad$ Mean & $\$ 27,332$ & $\$ 45,473$ \\
Median & 41.4 & 25.8 \\
$\quad$ Percent with income below \$20,000 & & \\
Pell Grant & $\$ 1,800$ & $\$ 1,240$ \\
Mean & $\$ 1,600$ & $\$ 0$ \\
Median & 58.1 & 42.1 \\
Any Pell & 46.0 & 30.4 \\
Neither parent attended college & 12.7 & 9.0 \\
Primary language other than English & 23.4 & 18.1 \\
One or both parents born outside US & & 68.3 \\
Race & 55.0 & 12.6 \\
White, non-Hispanic & 19.5 & 10.3 \\
Black, non-Hispanic & 16.6 & 8.8 \\
Hispanic & 9.0 & \\
All other & & 6,629 \\
\hline Sample size (unweighted) & 6,555 & \\
\hline
\end{tabular}

Source: Authors' calculations using FAFSA data from NPSAS: 2003-04. Sample is limited to 13,226 students (dependent or independent) first-year undergraduates who attended a single institution full time for the full school year and who were not missing key data elements such as income or actual EFC. Paper FAFSAs include those electronically submitted by financial aid administrators after collecting a paper FAFSA from the student. Income refers to parents' income for dependent students, or student (and spouse's) income for independent students. 
Figure 1. The Student Aid Application Process

Fall - Spring of Senior Year

\begin{tabular}{|c|}
\hline Student Applies \\
to Colleges \\
Student assembles and \\
submits college \\
applications, including test \\
scores, transcripts, \\
recommendations and
\end{tabular}

essays.

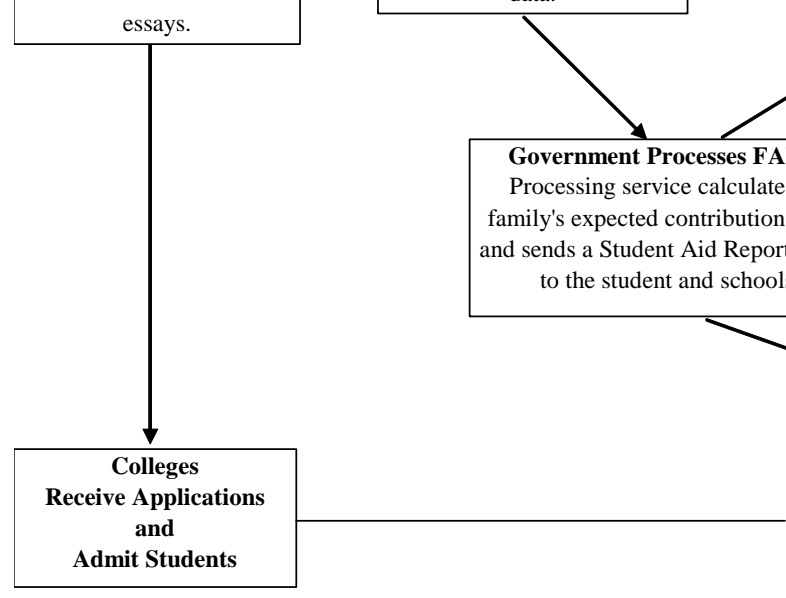
detailed demographic and financial data, and list up to six schools to receive FAFSA

data.
4-6 Weeks After Submitting FAFSA (2-3 weeks for on-line submissions)

Student Receives SAR The SAR provides the student's EFC and states whether he is eligible for a Pell Grant, but provides no dollar amount.

Government Processes FAFSA

Processing service calculates the

mily's expected contribution (EFC)

sends a Student Aid Report (SAR)

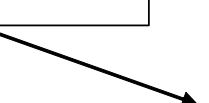

Schools Receive SAR and Assemble Aid Package

Financial aid offices use the EFC, the school's cost of attendance, and other information to design a package of federal, state, and institutional aid, which is then sent to accepted
March-April of Senior Year

Student Learns Aid Eligibility

Student learns about amount of

federal aid (Pell Grant, Stafford

Loans, work-study) and schoolspecific aid (scholarships and loans). students. 
Figure 2

How Does the Distribution of Grants and Loans Change if $80 \%$ of the FAFSA is Eliminated? Aid determined based on income and assets of parents and students, plus family structure Dependent and Independent Students
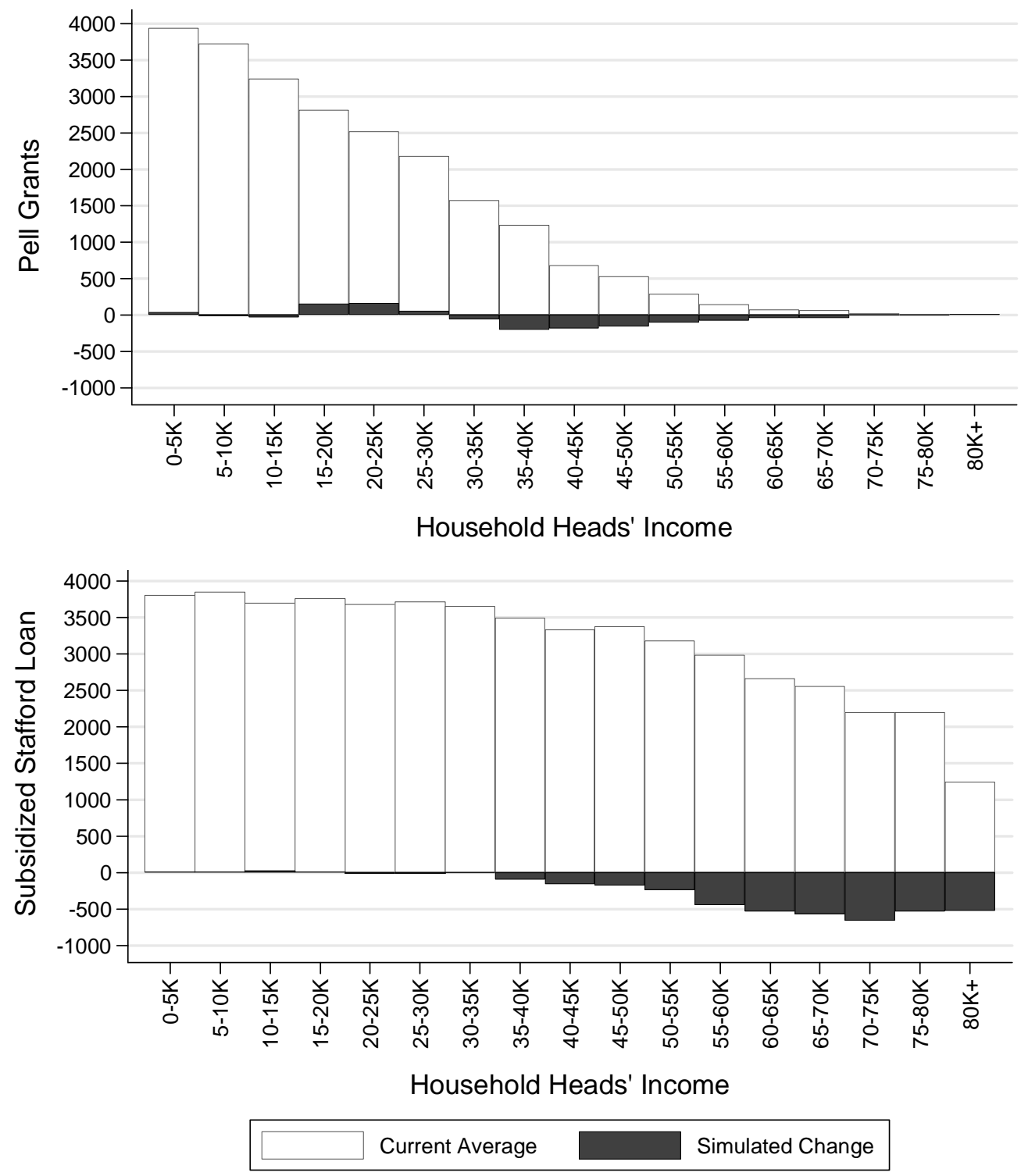

Note: Dollar amounts are in 2003-04\$ 
Figure 3

How Does the Distribution of Grants and Loans Change if Assets are Ignored?

Aid determined based on income of parents and students, plus family structure Dependent and Independent Students

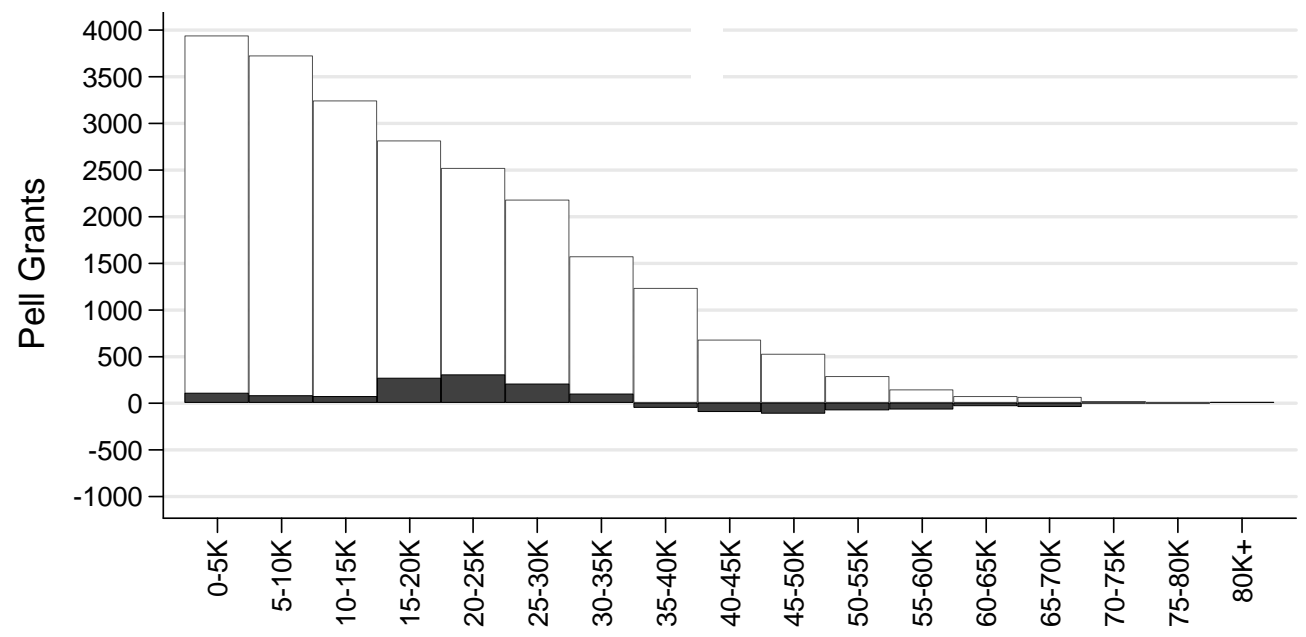

Household Heads' Income

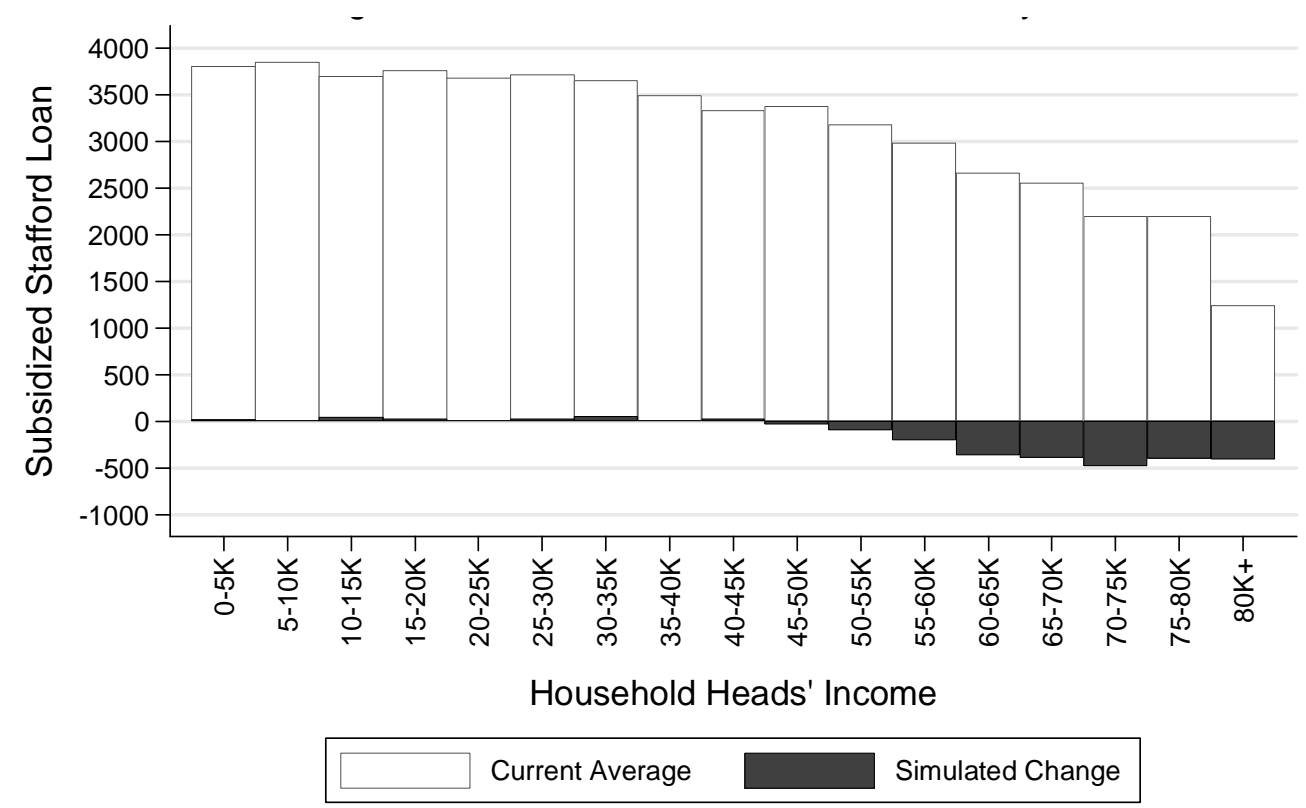

Note: Dollar amounts are in 2003-04\$ 
Figure 4

How Does the Distribution of Grants and Loans Change if Dependent Students' Earnings are Ignored? Dependent Students Only (independent students unaffected by this change)

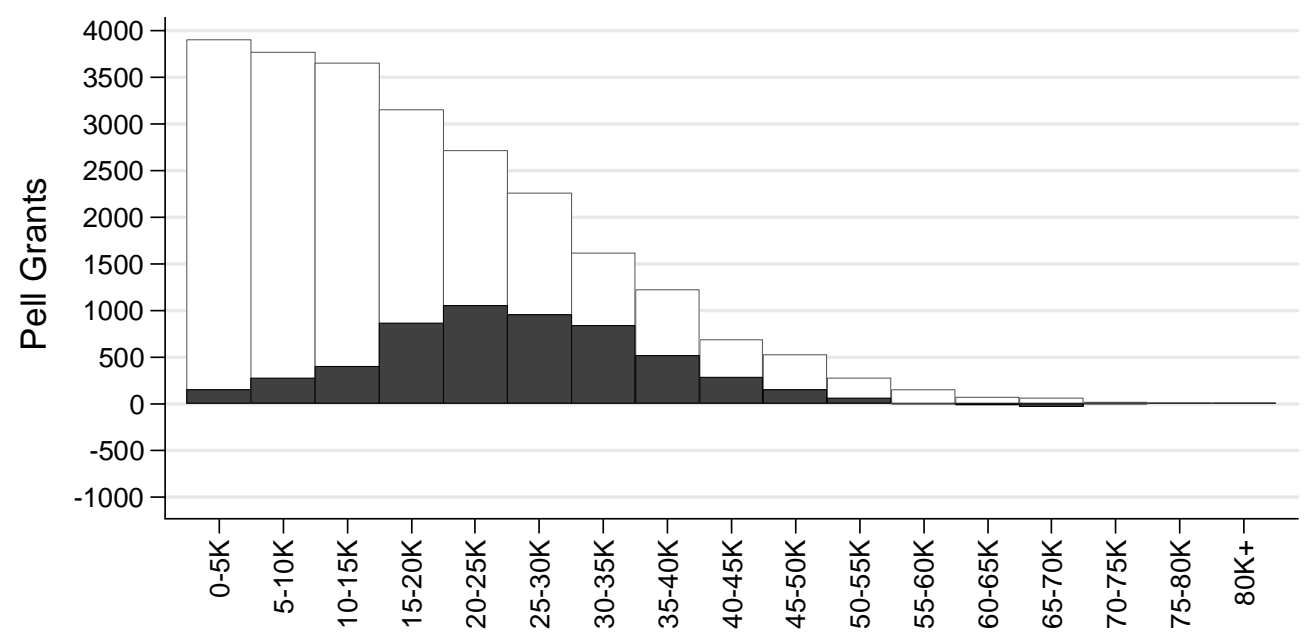

Parents' Income

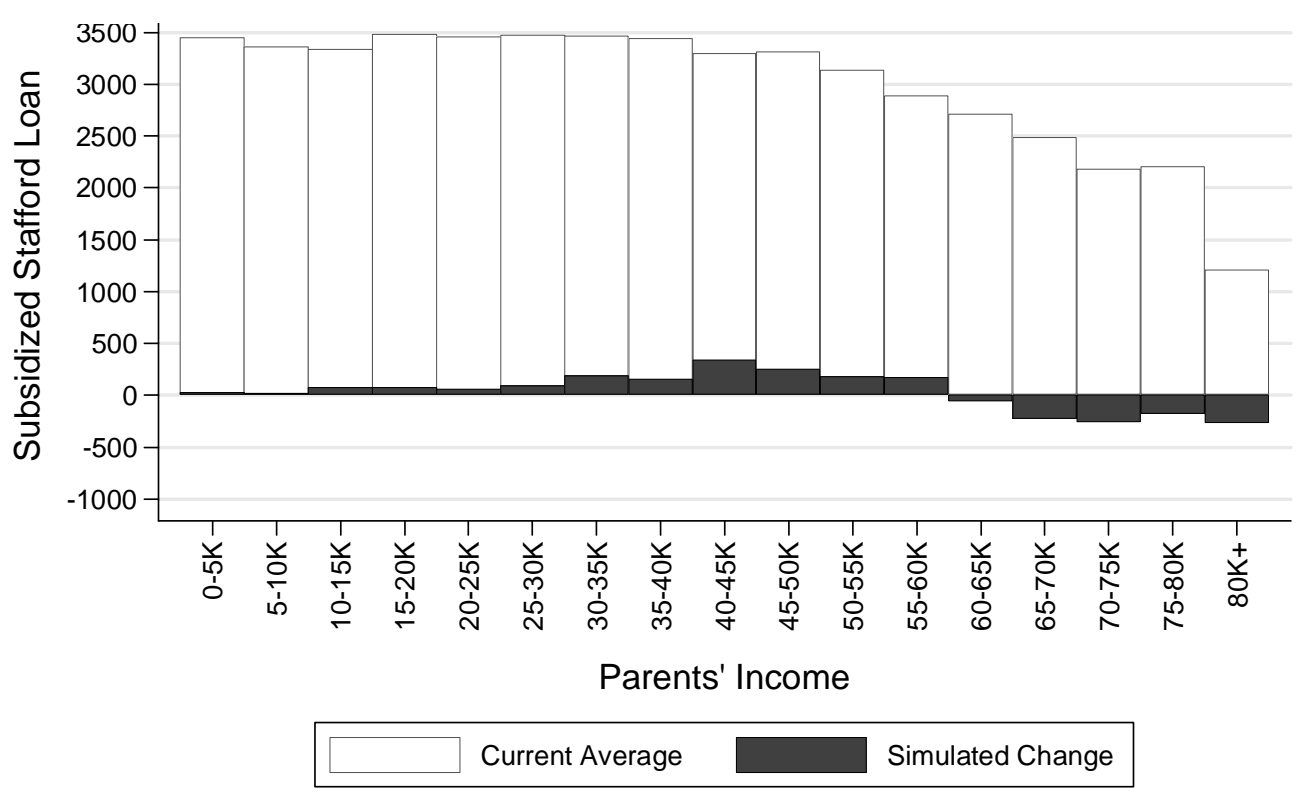

Note: Dollar amounts are in 2003-04\$ 